\title{
Otsides kvääre lugusid sõdadevahelise Eesti ajakirjandusest
}

\author{
Eugeenika rollist homoseksuaalsust ja transsoolisust \\ puudutavates aruteludes
}

\author{
Rebeka Põldsam \\ Tartu Ülikooli kultuuriteaduste instituudi doktorant \\ rebekap@gmail.com
}

\begin{abstract}
Teesid: Uurin artiklis seksuaal- ja soovähemuste representatsioone 1920.1930. aastate Eesti trükimeedias, et paremini mõista, mida tähendas soolisus sõdadevahelises Eestis ja kuidas see väljendus. Leitud allikates kostab marginaliseeritud inimeste endi häält harva ning paljud soolisuse mitmekesisust puudutavad mõisted olid sel perioodil defineerimata. See tekitab tänapäeva ja sõdadevahelise perioodi vahele epistemoloogilise lõhe, mida püüan artikliga leevendada. Seepärast annan artikli alguses ülevaate senisest Eesti LGBTQI+ ajaloo uurimisest, et näha seksuaalsust puudutavate mõistete kujunemist eri perioodidel. Seejärel kaardistan kahe sõja vahel Eestis seksuaal- ja soovähemuste kohta ilmunud ajakirjanduslikke ja teadusartikleid, mis juhatavad sisse juhtumiuuringu nn meesnaisest A. Oinatskist, kes oli selle perioodi kõige erinevamal viisil ja sagedamini kajastatud kväär inimene Eestis. Fragmentaarsete allikmaterjalide struktureerimiseks ja eritlemiseks tutvustan ja kasutan feministliku teoreetiku Karen Baradi agentse realismi mudelit, mille abil vaatan seksuaalvähemusi puudutava diskursuse näiteid ning lõpuks vaatlen, kuidas eugeenika liikumine mõjutas soolisuse ja seksuaalsuse kujutamist ja mõtestamist sõdadevahelise Eesti avalikes aruteludes.
\end{abstract}

Märksõnad: Karen Baradi agentne realism, LGBTQI+ meediauuringud, seksuaalsuse ajalugu, sõdadevaheline periood Eestis

2012. aastal tegi end esimeseks Eesti lesbikunstnikuks tituleerinud Anna-Stina Treumund fotosarja "Lilli, Reed, Frieda, Sabine, Eha, Malle, Alfred, Rein ja Mari”, mis loob kujutluspildi 16. sajandist 20. sajandi esimese pooleni elanud naistest ja transsoolistest, kellest enne Teist maailmasõda eestikeelses ajakirjanduses kirjutati. Fotosari teeb nähtavaks nähtamatuse, see tähendab: visualiseerib ajalookirjutuse lünga naiste elulugude ja ühiskondlike rollide kohal. Kõige rohkem on teada Lilli Suburgist, kelle kirjavahetusi, päevikuid ja elutööd on põhjalikult uurinud kirjandusteadlane Eve Annuk (Annuk 2019, 
2016, 2013). Kirjanik Reed Morni vähest tuntust põhjendab Rutt Hinrikus sellega, et modernistliku autorimüüdi juurde kuulub autori eluloo tuntus, aga Morni elust on vähe teada: erinevalt paljudest oma aja meesautoritest ei esinenud ta arvamusliidrina ega osalenud avalikus elus. Seega jäi ka tema looming kultuuriajaloos marginaalseks (Hinrikus 2016). Ratsutajate paarina kujutatud Frieda ja Sabine on väljamõeldud baltisakslased, kelle kunstnik on omavahel paari pannud, lähtudes 20. sajandi ajakirjandusest, kus homoseksuaalsust omistati rohkem välismaalastele ja baltisakslastele (Geenius-hull 1929; Lilla oudus 1933). Malle oli libahunt, Alfred oli nn meesnaine ehk transsooline inimene, Rein ja Mari olid transsooline rätsep ja talutüdruk, kes tahtsid 17. sajandil Väike-Maarjas abielluda, ning Eha on kunstniku väljamõeldud nimi meeste riideid kandnud naisele, kelle-sarnastest 1920. aastate Eesti ajakirjanduses korduvalt kirjutati (Treumund 2013).

Ma ei peatu pikemalt kunstiteose analüüsil, ent Anna-Stina Treumundi 2012. aasta fotosari on seni põhjalikem käsitlus eesti kvääride naiste ajaloost enne Teist maailmasõda. Sarjas joonistuvad välja olulisemad küsimused seksuaalvähemuste ajaloost Eestis: Miks ei ole midagi teada kvääride elulugudest? Mida on kväär erinevatel aegadel tähendanud ja missugustes narratiivides üldse ilmnenud? Kuidas leida jälgi kvääride elulugudest ja kuidas leitut mõista? Kuidas tõlgendada võimalike kvääride eluloolisi allikaid, kui tabude tõttu püüti oma seksuaalset erinevust turvalisuse kaalutlustel võimalikult hästi varjata, mis teeb tagantjärele nende intiimsfäärile tänapäevase sildi omistamise eetiliselt üsna problemaatiliseks nii mõistete erinevuse kui ka eraelu puutumatuse printsiipide pärast. Kuidas ajalugu kirjutades või kunstis visualiseerides kujutada ajaloolist soolist vägivalda võimalikult täpselt ja kriitiliselt?

Jätkan Anna-Stina Treumundi algatatud uurimust Eesti ajaloos ning otsin ja mõtestan kriitiliselt soo- ja seksuaalvähemuste representatsioone sõdadevahelises Eestis. Alljärgnevalt süstematiseerin feministliku teoreetiku Karen Baradi representatsioonikriitilisele metoodikale toetudes kahe ilmasõja vahel Eestis ilmunud seksuaal- ja soovähemusi käsitlevate artiklite kogumit, mille leidsin Eesti digiarhiividest, kasutades LGBTQI+ (lesbi, gei, bi, trans, queer ja intersooliste inimeste) teemalisi märksõnu, mis on ajalooliselt kasutusel olnud. Siinse artikli metodoloogiliseks baasiks ja kirjutamise kontekstiks on viimase kümne aasta jooksul oluliselt kasvanud Eesti kvääriajaloo uurimislugu, mille visandan artikli esimeses alapeatükis. Senine Eesti kvääri-uurimine on käsitlenud rohkem Teise maailmasõja järgset ajalugu, toetudes intervjuudele, elulugudele, kohtutoimikutele, ning on tihti seotud nüüdiskunsti teostega. Teises alapeatükis tutvustan oma uurimistöö metodoloogiat ja teoreetilist raamistikku. Kolmandas osas tutvustan leitud lugusid ning analüüsin nn meesnaisena tuntud ja aastatel 1929-1934 pisivargustega korduvalt Eesti ajakirjanduse tähelepanu 
pälvinud A. Oinatski juhtumit. Anna-Stina Treumundi aitas ajalooliste allikate leidmisel kirjandusloolane Vahur Aabrams, kelle sõnul tehti pärast näitust ühiselt plaane käsitleda kunagi eraldi A. Oinatskit - ühte Treumundi fotosarja inspireerinud ajaloolistest kvääridest. Treumundi surma järel plaanid katkesid, aga Aabrams jagas minuga selleks kogutud arhiivimaterjale.

\section{Eesti kvääriajaloo uurimistee}

Mis on Eesti kvääriajalugu? Kõigepealt võiks selleks lugeda homoseksuaalsete ja transsooliste inimeste elulood ja niisugused ajaloosündmused, milles on rolli mänginud inimeste sooline või seksuaalne kuuluvus. Aja jooksul on kvääri mõiste teoreetilistes aruteludes kujunenud laias laastus kõikvõimalike mittenormatiivsete intiimelukaarte tõhusaks analüüsivahendiks (Taavetti 2018a: 33-34). Nii võis 20. sajandi alguses poisipead kandev naine Tartus või vanatüdrukupõlve valinu mõnes külas mõjuda sama raskesti mõistetavalt ja võorikult ehk kväärilt kui 21. sajandi teisel kümnendil mõjuvad inimesed, kes ei identifitseeri end ei mehe ega naisena, vaid käsitavad soolisust avatud ja aktiivse protsessina, kuigi pealtnäha võivad nad elada n-ö tavalise mehe või naisena. Siinse artikli keskmes ongi kvääriteooria laiem käsitus, mis püüab arvestada nii uuritava aja kui ka uurimise läbiviimise aja arusaamasid. Alljärgnevalt visandan Eesti kvääriajaloo uurimistee, kus selgub, et seni on Eestis LGBTQI+ ajaloo küsimustega enne ajaloolasi tegelenud just kunstnikud AnnaStina Treumund ja Jaanus Samma. Kunstnikud on konsulteerinud ajaloolastega, kes hiljem on kasutanud samu materjale oma uurimuses.

2015. aastal ilmus kunstnik Jaanus Samma näituse "NSFW. Esimehe lugu" ingliskeelne kataloog, mis esitas anonümiseeritud ja toimetatud kujul loo 1960. aastatel mehega seksimise eest karistatud kolhoosiesimehest (Samma jt 2015). Samma allikateks olid Esimehe kohtutoimik, tema isiku ja aja kohta kogutud mälestused ja kuulujutud. Kunstinäitusel ja kataloogis analüüsiti, kontekstualiseeriti, tõlgendati ja eksponeeriti Esimeheks hüütud eesti mehe loo erinevaid tahke alates tema erandlikult pööreterohke isikliku elu narratiivist kuni totalitaarse riigikorra kontrollimehhanismide groteskini. See polnud lihtsalt lugu ühest õnnetult režiimi hammasrataste vahele jäänud mehest, vaid näitas ajaloo ja indiviidi kompleksseid vastastiksuhteid, muuhulgas neid, mille alusel saab midagi või kedagi üldse kvääriks pidada, lähtudes sugu ja seksuaalsust kriitiliselt mõtestavast teoreetilisest sõnavarast.

Esimehe lugu kasvas välja Jaanus Samma 2010. aastal alguse saanud dokumentaalteosest "Jutustamata lood" (2011), mille tellisime kuraatoritena Airi Triisbergi ja Anders Härmiga Ida-Euroopa LGBTQI+ narratiive käsitlevaks 
aktivistlikuks kunstinäituseks "Sõnastamata lood" (2011, Tallinna Kunstihoone). Nõukogude ajal elanud homoseksuaalsete meestega intervjuusid kogudes Samma Esimehe avastaski ning nii tekkis küsimus, kas selliseid lugusid on Eestis veel. Kas ka naistest või transsoolistest võiks leiduda lugusid enne taasiseseisvumisaega? Samu küsimusi püstitas kogu oma kunstipraktikaga Anna-Stina Treumund, kes visualiseeris lesbi- ja naisajalugu ja kogukonda, ning kelle loomingut on süvitsi analüüsinud Redi Koobak (Koobak 2013). Igal juhul hakkas 2011. aastast mitmes uurijas tasapisi tekkima huvi Eesti kvääriajaloo vastu, mille varjatud narratiivid ja nende otsimine erinevad oluliselt USA kultuuri- ja seadusruumist väljakasvanud queer-teooria peavoolust, kus põhirõhk on n-ö kapist välja tulemise identiteedil ja võrdõiguslikkuse aktivismil, samas kui Eesti kvääride lugude uurimine nõuab teistmoodi lähenemist varjatud lugude leidmiseks, intiimsete juhtumite ja saladuste tagantjärele väljatoomiseks ja käsitlemiseks.

Jaanus Samma uurimust "Esimehe lugu" analüüsis ka soome ajaloolane Riikka Taavetti, kes lisaks "Esimehe loole" ja selle retseptsioonile on võrrelnud 1990. aastatel kogutud Eesti ja Soome seksuaalsuse teemalisi omaeluloolisi kirjutisi ja kogumikke ning käsitlenud prostitutsiooni kui Nõukogude Eesti kvääri nähtust (Taavetti 2018a). Lisaks on Taavetti analüüsinud väliseestlase Heljo Liitoja memuaare "See puuduv osa" (2002), mis jutustab loo Teise maailmasõja põgenikust 1960. aastate Kanadas, kus geide seltskonda sattumine tekitas heteronormatiivseid väärtusi kandvas väliseestlaste kogukonnas üsna aktiivses rollis olevale naisele mitmeid (sise)konflikte (Taavetti 2018b).

Folklorist Andreas Kalkun on Jaanus Samma jälgedes uurinud Eesti kohtutoimikuid ning leidnud sõdadevahelise perioodi sugukõlvatute tegude kriminaalmenetluste arhiivist kolm juhtumit, kus mehi on karistatud meestega seksimise või selle soovi avaldamise eest, neist üks juhtum pälvis avalikkuse tähelepanu ka omaaegses ajakirjanduses (Kalkun 2018). Lisaks juhtumite põhjalikule analüüsile ja küsimustele kohtutoimikute kui fragmenteeritud ja efemeersete materjalide olemusest allikatena, andis Kalkun ülevaate sõdadevahelisel perioodil Eesti Vabariigis aset leidnud homoseksuaalsuse dekriminaliseerimisest ja seda puudutavatest avalikest debattidest, mis kestsid visalt 1930. aastate keskpaigani, mil paradoksaalselt samaaegselt "vaikiva ajastu" saabumisega jõustus homoseksuaalsuse dekriminaliseerimine (Jõeäär 1926, Uus Sõna 1935). Kuna toona oli üks tähtsamaid tollal ebanormaalseks peetud seksuaalsusega inimeste ja nende võrdõiguslikkuse eestkõnelejaid Berliini seksuoloog Magnus Hirschfeld, uuris Kalkun Hirschfeldi tegevust ja seoseid Eestiga ning tema visiite Eestisse oma ettekandes 2019. aastal Eesti Kirjandusmuuseumis toimunud seminaril "20. sajandi alguse Eesti kväärimine". Samal seminaril esines ka Kai Stahl, kes uurib 1920. aastate alguses 
loometeed alustanud kunstnik Natalie Mei kvääri alter ego't ja loomingut, kus kasutas allikatena peale varasemate kunstiteaduslike uurimuste hiljuti leitud kirjavahetusi ja päevikuid.

Homoseksuaalsuse ja seda puudutava seadusandluse kohta Nõukogude Liidus ilmus 1990. aasta konverentsi ettekannete põhjal koostatud kogumik "Sexual Minorities and Society: the changing attitudes towards homosexuality in the 20th century Europe" ("Seksuaalvähemused ja ühiskond: suhtumise muutumine homoseksuaalsusse 20. sajandi Euroopas", 1991), mis lisaks ajaloouurimuslikule sisule on tänaseks kujunenud iseseisvaks uurimisobjektiks. 1990. aastal Tallinnas toimunud konverentsi ühe korraldaja ja kogumiku koostaja Teet Veispaku ettekanne andis ülevaate ENSV Justiitsministeeriumi arhiivist leitud statistikast, mille põhjal aastatel 1960-1989 karistati homoseksuaalsuse paragrahvi alusel ühtekokku 159 meest. Ivika Nõgeli ettekanne tema 1989. aastal kaitstud diplomitööst, millega seoses viis Nõgel Tallinna kõrgkoolide 22aastaste tudengite seas läbi suhtumisküsitluse, näitas, et sooneutraalselt võrdsetesse abielu- ja lapsendamisõigustesse suhtus tollaste üliõpilaste enamus pigem soosivalt. Ühtlasi andis Nõgeli ettekanne ülevaate 1980. aastate lõpu raadios ja trükimeedias toimunud diskussioonidest aidsi ja homoseksuaalsuse teemadel, mis aitab tulevikus neid materjale paremini leida (Nõgel 1991).

Lisaks neile ajaloolistele uurimustele leidub Eesti LGBTQI+ kultuuriloolilisi käsitlusi artiklikogumikus "Kapiuksed valla” (Davidjants 2010). Seniavaldamata uurimusi ettekandepäevadelt (Kuusik 2018; Lember 2018; Kalkun 2019; Ross 2019; Stahl 2019) ning kaudselt seksuaal- ja soovähemuste ajalooga seostuvaid uurimusi (Ird 2013) võib leida veel. Siinse historiograafilise ülevaate põhjal võib üldistada, et seniste uurimuste keskseks huviobjektiks on seksuaalvähemustesse kuuluvate inimeste ütluste ehk oma hääle, elulugude või nende fragmentide otsimine ja tõlgendamine seoses seadusandlusega või avalikku ruumi jõudnud aruteludega külajuttudest, kirjandus- ja kunstiteosteni ning teadus- ja ajaleheartikliteni.

Selle põhjal võib öelda, et Eesti kvääriajaloo uurimine on alles nii fragmentaarne, et ühegi 20. sajandi perioodi kohta ei saa veel teha üldistusi, mis ulatuks leitud materjalide analüüsist kaugemale. Samas on peaaegu kõik ülalmainitud uurimused omavahel seotud seeläbi, et uurijad on omavahel tuttavad ning täiendavad üksteise leide. Siinne artikkel asetub teadlikult Eesti kvääri uurimislukku, kus püüan leitud tekstikorpuselt küsida juba varemgi küsitut ning esitada kummatigi uusi küsimusi seksuaal- ja soovähemuste ajalooliste representatsioonide kohta, olles teadlik, et need mõisted on pidevas muutumises ning paljud kvääride lugusid teadvad inimesed, nende mälestused ja teised allikad on ajas kaduma läinud. 


\section{Seksuaalvähemuste representatsioonide otsingumeetod}

Kui hakkasin Eesti seksuaal- ja soovähemuste ajalugu uurima, pidin materjali suhtelisest nappusest hoolimata seadma kõigepealt selged piirid ja sõnastama küsimused, kuidas vähemusgruppe ajalooliselt ja keeleliselt määratleda, milliste allikatega töötada ning milliseid aspekte vähemuste ajaloos käsitleda, et allikmaterjali erisuguseid omadusi võimalikult hästi välja tuua. Ajaloolane Estelle Freedman on lesbiajaloo peamiste uurimisallikatena nimetanud kirjavahetusi, meditsiini- ja kohtutoimikud (Freedman 1982: 110), mis üldjoontes kehtivad kõigi LGBTQI+ gruppide kirjutamata ajalugude kohta. Kui kunstiteoste puhul saan toetuda teoste tõlgendamisele, retseptsioonile, kunstnike ütlustele, kuulujuttudele, mälestustele ja nende faktikontrollile, siis siinses artiklis lisanduvad kunstile veel ilu- ja teaduskirjandus, ajakirjandusarhiivid ja interneti kaudu rahvusvahelised digiarhiivid. Ajakirjanduses ringlevad representatsioonid annavad aimu, kuidas kõrvaltvaataja pilk on kvääre ja nende kujutamise kaudu norme loonud. Siinses artiklis on minu peamisteks allikateks internetis kättesaadavad digiteeritud eestikeelsete ajalehtede ja ajakirjade andmebaasid DEA, Digar, e-raamatukogu Etera ning Google'i otsingumootoriga leitud artiklid, samuti Eesti eugeenika ajalugu puudutavad uurimused ja neis viidatud sõdadevahelisel perioodil ilmunud seksuaalkasvatust käsitlevad raamatud. Lisaks tutvusin mõnede Rahvusarhiivi toimikutega, mis puudutasid ajalehtedes mainitud inimesi ja lokaale, kuid ei andnud esialgu teistele siinmainitud allikatele sisulisi lisandusi. Materjali struktureerimiseks toetusin Karen Baradi agentse realismi teooriale, mida tutvustan allpool.

Minu huvi sõdadevahelise perioodi trükimeedia vastu sai alguse Lola Annabel Kassi, Mirjam Hinrikuse ja Liis Pählapuu näitusest "Kurja lillede lapsed. Eesti dekandentlik kunst" (2017, Kumu kunstimuuseum), mille üheks teemaliiniks olid androgüünsed autoportreed kui kunstnike ühiskonnakriitiline enesekujutamine. Lisaks saatis Hinrikus mulle meilivahetuses Johannes Semperi 1926. aastal ilmunud lühijutu "Niidukressid", mis ilmus nn uut naist kujutavas novellikogumikus "Ellinor". "Niidukressid" on lugu rikkast maskuliinsest proua Liibeonist, kes püüab manipuleerides ja võimutsedes endale kaaslannat leida. Mind haaras otsekohe küsimus, kes võiks olla loo prototüüp ning Google’i otsing juhatas mu kiiresti Digari Postimehe arhiivi, Albert Kivikase 1928. aastal ilmunud arvustusteni. Kivikase kirjutistest selgus, et Semperi raamat on Paul Morandi 1922. aasta novellist "Rooma öö" inspireeritud ja Eestisse kohandatud teisend (Kivikas 1928ac). Semper vastas Kivikale, ning nende mõttevahetusest kujunes Lääne laenude ja eesti rahvuslike väärtuste vaheline konflikt (Kivikas 1928b; Semper 1928ab). Lisaks Kivikase pilkavatele arvustustele ilmus Võru 
Teatajas ka toetavam arvustus, mis oli proua Liibeoni kujust pigem positiivselt intrigeeritud (Võru Teataja 1928). Ometi osutus Kivikase retseptsioon eriliselt väärtuslikuks, kuna andis mulle proua Liibeoni kohta märksõna naismees, kellesugustest avalikult kirjutamise Kivikas hukka mõistis, kuna see viivat seesuguste inimeste Eesti tänavapilti ilmumiseni (Kivikas 1928d).

Niisiis alustasin otsinguid digiteeritud ajalehtede andmebaasis Digar, katsetades igasuguste märksõnadega, mida teadsin varasemast ning mida LGBTQI+ ajaloo käsitlusi veebis ja trükisena lehitsemisel ning arhiiviartikleid lugedes järjepanu lisandus. Kõige sagedamini esinev märksõna tänapäeva mõistes LGBTQI+ inimeste kohta sõdadevahelise perioodi trükimeedias on 'meesnaine' ning vähemalt kolmandik leitud artiklitest räägivad meheriietes naistest või naiseriietes meestest. Lisaks sellele katsetasin erinevaid kirjaviise homoseksuaalsust, lesbilisust ja transsoolisust tähistanud sõnadega ning rahvusvaheliselt tuntud ajalooliste LGBTQI+ inimeste nimedega (millest tulemusi andsid Magnus Hirschfeld, Richard Kraft-Ebbing, Oscar Wilde, Elisar von Kupffer, Marlene Dietrich, Greta Garbo, Jean Cocteau, André Gide, Rosa Bonheur, Platon, Sokrates, Sappho, Lily Elbe, vennad Tšaikovskid). Arhiveerisin leiud viidetega oma arvutisse ning jagasin neid kohe teiste uurijatega, lootes, et mitmes arvutis säilivad erinevate sõnakujude süsteemse katsetamise kaudu väljaotsitud materjalid kindlamalt. Samas tahtsin julgustada teiste käimasolevat või potentsiaalset uurimistööd ning õhutada neid endaga kaasa mõtlema, mida leitud materjalidega edasi teha.

Koondasin materjale mitmes järgus, alustades märksõnade kaardistamisega ning jätkasin süstematiseeritud ja põhjalikuma lugude väljaotsimisega. Kokku olen seni leidnud umbes 300 artiklit, mis mainivad või käsitlevad seksuaal- või soovähemusse kuuluvaid inimesi või vastavat subkultuuri. Koostöös otsimist katsetasin märtsis 2019, õpetades Tartu Ülikoolis kursusemoodulit, kus palusin osalejatel otsida Eesti veebiarhiividest seksuaal- ja soovähemuste representatsioone ning leitud materjale analüüsida. Tudengid leidsid minu kogule lisaks 43 uudisnuppu, artiklit ja fotot. Allikatena kasutatud artiklid on vastavalt väljaannetele küllalt erinevad: arstide seltsi väljaannetes avaldati meditsiiniteadlaste arutelusid, teatavat erialakirjanduse eesmärki kandsid spordilehed ning kümmekond reportaaži, mis refereerisid teaduslikke raamatuid või loenguid; mitmed pikemad artiklid ilmusid huumorilehtedes või päevalehtede meelelahutusrubriikides, arvestatav hulk artikleid ilmus krimiuudistes. Tulevikus võiks kaaluda laiema seksuaalsuse spektri ja nende representatsioonide analüüsiks näiteks žanrimääratluste analüüsi eri väljaannetes.

Kuigi digiteeritud arhiivimaterjalid on päästetud ainelisest hävingust ning tänu tekstitöötlusprogrammidele saab neid kasutada efektiivsemalt kui arhiivis kõiki materjale läbi lehitsedes, on digiarhiivide miinuseks nende fragmen- 
taarsus. Esiteks ei tule sõnaotsingutega välja kvääridest kaudselt rääkivad artiklid ning kõiki ajalehtede skaneeringuid programm ei tuvasta. Seetõttu kujuneski väga oluliseks arhiivindust õppinud Taavi Koppeli kogumistöö, kes tutvustas mulle 1933. aastal Rahvalehes ilmunud pihtimuslikku fiktsionaalset artiklisarja "Lilla õudus", mis jutustas kümne aasta pikkuse vaatluse põhjal homoseksuaalsete meeste suhtlusvõrgustikest Tallinnas ja mujal Eestis. Seda artiklikogumit ei leidnud ma ühegi sõnaotsinguga ka hiljem katsetades. Seega tuleb märkida, et Digari tekstituvastusprogramm ei ole täiesti töökindel ning võtta arvesse, et ilmselt pole ma paljusid materjale veel üles leidnud. Sellest järeldan, et praegune sõnaotsingute abil leitud kogum ei ole ammendav ega anna võimalust teha leitud materjali põhjal uuritava perioodi kohta kaugeleulatuvaid järeldusi.

Esimesteks refleksiooniküsimusteks siinse artikli juures kerkisid otsisõnade väljamõtlemine, ajaliste ja sisuliste piirangute seadmine, leidude süstematiseerimine ja tähenduste määratlemine. Ajaliseks piiriks seadsin esialgu aastad 1900-1945. Kõige rohkem artikleid ilmus aastail 1928-1933, vahemikus 1919-1939 ilmus igal aastal vähemalt üks artikkel, mille järgi siinse artikli ajaliselt raamistasin. Ülejäänud perioodi leiud on sporaadilisemad. Teiseks pidin otsustama, milliste teemadega piirdun, sest 21. sajandi kvääriteooria järgijana eristan soolisuse ja seksuaalsuse mitmekesisuse spektreid oluliselt detailsemalt kui seda tehti enne Teist maailmasõda. Pean silmas, et kuigi pedofiilide hulgas on ka samast soost laste kuritarvitajaid ja sodoomia on Piiblis olnud kasutusel homoseksuaalsete meessuhete kirjeldamiseks, mõistan pedofiliat ja sodoomiat selgelt homoseksuaalsusest eristuva nähtusena, sest homoseksuaalsust ei defineeri isiku- ega loomadevastane vägivald. Samas - nagu uurimistulemustest selgub - ei olnud sõdadevahelisel perioodil heteroseksuaalsusest erineva soolise ja seksuaalse subjektsuse, identiteedi ja praktika erisused diskursiivselt veel tingimata välja kujunenud ega eristavalt mõistetud. Mõnel puhul näib, et kõiki praktikaid, mis polnud heteroseksuaalsed, peeti kas psühhopatoloogiaks või lausa roimaks (Viidik 1937: 75). Lisaks otsustasin oma kogumist kõrvale jätta sellised nähtused nagu vabaarmastus ja nudism ehk naturism, mis küll hõlmavad kõiki sugusid ja seksuaalseid orientatsioone, kuid mille kohta leidus vähe sellist infot, mis oleks seksuaal- ja soovähemuste lugude mõistmist sisuliselt täiendanud. Kogu seksuaal- ja soospektrumi uurimine pole siinse uurimuse eesmärk.

Otsustasin siinses artiklis kasutada vaheldumisi sõdadevahelist soolisuse ja seksuaalsuse diskursust ning tänapäevaseid mõisteid. Olen teinud nii ühelt poolt selleks, et vanu lugusid tänapäeva inimesele arusaadavaks "tõlkida", teisalt selleks, et distantseeruda praegusajal homofoobsena mõjuvast retoorikast, mida sõdadevahelisel perioodil tingimata sellisena ei mõeldud. Näiteks 
1930. aastatel kasutatud "soovahetuse" asemel on täpsem kasutada mõistet "soo korrigeerimine", sest operatsiooni ja riietumise abil esitab transsooline inimene sugu, millega ta identifitseerub, mitte ei vaheta seda (Stryker 2017: 10, 20-21). Lisaks olen siinses artiklis jätnud kõrvale homofoobse diskursuse omnipresentsuse, sest peaaegu kõik artiklid väljendavad seksuaalvähemuste suhtes kas otsest pahatahtlikkust, mõistmatust, skepsist või kaastunnet. Veel enam - nagu A. Oinatski juhtumist allpool selgemalt välja joonistub, domineeris seksuaal- ja soovähemuste mõtestamisel nn negatiivse eugeenika diskursus, mis paralleelselt pronatalismiga kuulutas homoseksuaalsuse ja transsoolisuse patoloogiaks või kuritegevuseks, mida piirata ja millest hoiduda. Tänaseks on koos eugeenika hääbumisega ka homoseksuaalsus ja transsoolisus haiguste nimekirjadest eemaldatud ja Eestis dekriminaliseeritud.

Otsingumeetodi ja sõnavara kõrval otsisin teoreetilise analüüsi vahendeid, mille abil leitud materjali mõtestada. Leidsin sobivaks mudeliks Karen Baradi agentse realismi, mis seab eesmärgiks uuritava erinevate osiste agentsete ehk tegevate seoste märkamise ning mille kaudu saan oma artiklivalimi diskursusi süstematiseerida. Et arhiivimaterjalid kujutavad endast ainult fragmente Eesti kvääri-tegelikkusest, kasutan Karen Baradi representatsioonikriitilist meetodit raamatust "Meeting the Universe Halfway" (2007). Baradi teooria ühendab Michel Foucault' diskursuseanalüüsi ja genealoogia ideed Judith Butleri performatiivsusteooria ja Donna Haraway pidevas vastastikuses mõjus kujunemise (becoming-with) ideede vahendusel Niels Bohri kvantfüüsika komplementaarsusprintsiibi mudeliga (Barad 2007: 61-67). Barad on oma teooria väljaarendamiseks loonud uudissõnu ja -mõisteid, millega ta arendab edasi varasemate autorite teoreetilisi väljendeid. Näiteks mõtestab Barad Foucault'd teiste autorite vahendusel, mitte n-ö puhtal kujul, mistõttu rõhutab ta Foucault' diskursuse mõiste feministlikuks eristuseks selle materialistlikku väärtust ehk seda, kuidas mõistmine on diskursiivne praktika materiaalse kuju ja tagajärgedega, kasutades terminit materiaal-diskursiivsed praktikad (materialdiscursive practices) (Barad 2007: 147).

Baradi teoreetiline mudel toetub Niels Bohrile, kelle järgi objektiivsus kui selline on võimalik ainult konkreetselt mõõdetavas ja vaadeldavas (katse)situatsioonis, kusjuures vaatlusvahenditega (measuring agents) koos muutuvad ka tulemused (Barad 2007: 117-118). Bohri sõnastatud nähtuse (phenomenon) mõistest - mille tähendus toimib üksnes vaadeldavas olukorras, aga mitte universaalselt igal pool - lähtuvalt on Barad kirjeldanud nähtuse vaatlusaparatuuri (measuring apparatus), kus nähtus ilmneb alati seotud suhtlusvõrgustikus (entanglement) ning tähendused tekivad intra-aktsioonide (intra-action) kaudu, näiteks materiaal-diskursiivsete praktikate vahendusel (Barad 2007: 178). Seega Baradi mudeli järgi tekivad tähendused suhtlusvõrgustiku tegevuse 
käigus. Nähtust ja selles toimuvat piiritlevad vaatlusvahendite (näiteks minu kui vaatleja) võimed seoseid märgata. Mina uurin seksuaal- ja soovähemusi, kelle hulka kuuluvatest inimestest ilmunud lugusid leidub mitmesugustes diskursiivsetes režiimides, näiteks teadustekstides ja krimiuudistes, mis on omavahel materiaal-diskursiivsete praktikate - diskursiivsetel mõistmistel on materiaalsed tagajärjed - kaudu seotud ning moodustavad väljaannete, autorite ning sellel ajal levinud sugu ja seksuaalsust puudutavate teadmiste seotud suhtlusvõrgustiku. Sellises mudelis materjali vaadates selguvad seosed ja argumendid, mida diskursusi genealoogiliselt kaardistamata ja võrdlevalt analüüsimata oleks keerulisem märgata.

Niisiis on tähenduste selgitamiseks ja arutamiseks oluline läbipaistvus ja elementide kaardistamine genealoogiana. Nagu öeldud, toimivad mitutpidi ristuvad seosed, intra-aktsioonid materiaal-diskursiivsete praktikate abil. Sealjuures on intra-aktsioon intersektsionaalsuse ehk sotsiaalselt mitmedimensioonilise analüüsi vahend, mille järgi miski pole ühene, kuna tähendused sünnivad diskursuses, mis omakorda koosneb intra-aktsioonidega seotud suhtlusvõrgustikest ning seeläbi on märgatavalt asjasse puutuvad seosed tähenduste tekkimisel agentses rollis. Vaatleja peab suutma otsustada, mis osad on nähtuses olulisena määratletavad (Barad 2007: 97-131). Nagu alljärgnevast selgub, on kirjutised seksuaal- ja soovähemustest sõdadevahelises Eestis intraaktsioonide kaudu seotud eugeenika ideedega, mis aitab näha diskursiivseid seoseid, kuidas homoseksuaalsust ja transsoolisust tol perioodil patologiseeriti ja heteronormatiivsust propageeriti.

Ainesega suhestumist toetab Baradi teooria binaarsusest hoiduv loogika, mis suunab vastanduste asemel otsima täiendusi. Binaarsust vältiva mõtlemise puhul on oluline roll eri elementide agentsusel, st selleks, et vaadeldav nähtus saaks väljendada erinevates olukordades erinevaid valikuid, peab tal olema teatav võimalus toimida (perform) rohkem kui ühtmoodi (Barad 2007: 135-136). Sellepärast ongi Baradi loodud eri autorite koosmõjulise genealoogilise vaatlusskeemi nimetus agentne realism, et nn objektiivne tegelikkus saabki eksisteerida ainult vaadeldavas agentsete seoste vahelises protsessis (Barad 2007: 137-141). Representatsioonid iseenesest - antud juhul mõnisada artiklit, mis puudutavad kvääriajalugu - ei tähenda eriti midagi, s.o nende põhjal ei saa teha üldistusi seksuaal- ja soovähemuste ühiskondliku positsiooni kohta sõdadevahelises Eestis. Ent kui representatsioonid genealoogiliselt süstematiseerida, on võimalik vaadelda, kuidas ja millistes seostes tekivad tähendused seksuaal- ja soovähemustest ning millised on nende tähenduste materiaalsed väljundid, näiteks seaduste ja inimeste intra-aktsioonid kui inimeste tegevuse ja avaliku diskursuse normide kujundajad. 


\section{Kväärid lood sõdadevahelisel perioodil}

Siinses alapeatükis tutvustan ülevaatlikult seksuaal- ja soovähemustest leitud lugusid sõdadevahelise Eesti ajakirjanduses. Otsisin pikalt sõna "homoseksuaalsus" erinevaid kirjapilte ja tüvelt sarnaseid sõnu, nii osutuski see otsisõna üheks sagedamaks vaste andjaks. Homoseksuaalsusest kirjutati kui sensatsioonist, meditsiinilisest nähtusest, perversioonist, ühesoolistes institutsioonides nagu sõjavägi või vangla levinud probleemist, geeniuseks olemise eeldusest, halvast abielumaterjalist, eugeenilisest nähtusest, nagu võib näha näiteks bibliograafias väljatoodud artiklitest, mis ilmusid väljaannetes Päevaleht, Postimees, Kaja, Rahvaleht, Sakala, Uus Kosjaleht, Uudisleht, Eesti Arst. Selle sõnaga seoses räägiti enamjaolt meestest ja väga harva mööndi, et ka "niisuguseid naisi" on olemas (Uus Kosjaleht 1932; Tallinna Post 1932; Kaja 1929). Homoseksuaalsete meeste kohta ilmus mitu põhjalikku lugu, mis mainisid näiteks tuntud homoseksuaalseid autoreid Sokratesest Tšaikovskini kui tõestust selle nähtuse olemasolust ja inimlikkusest, juhatamaks sisse Tallinna meeste "lantimisala" kirjeldust (Uus Kosjaleht 1932). Anonüümse autori artiklisari "Lilla õudus" andis jällegi pikema sissevaate teemasse, kuidas meeste juhututvused kulgesid, kus homoseksuaalsed mehed omavahel kohtusid, suhtlesid, kuidas pidutsesid ja missuguseid rituaale veel läbi viisid (Lilla õudus 1933). Enamjaolt oli artiklite tonaalsus ambivalentne: selgitati homoseksuaalsuse tähendust tänapäevani käibel olevas mõttes, samal ajal esitati seda nähtust kaastundeväärilise ja saatuslikult ebanormaalsena (Uus Kosjaleht 1932; Lilla õudus 1933).

Kvääride naiste puhul aga sai populaarsemaks märksõna "garçonne" mille alternatiiviks olid "poisitar" ning valdavalt kasutati neid sõnu Lääne kultuuritegelaste kohta. 'Poisitari' sõna kasutati segamini nii moodsate n-ö androgüünsete naiste kohta ja garçonne'ilike naiste kohta, keda me tänapäeva LGBTQI+ ajalugudes tunneme lesbide, biseksuaalsete naiste ja feministidena (Zirk 1934; Naisterahva Elu 1925). Ometi olid naiste puhul veelgi olulisemaks märksõnadeks eelnimetatud "naismees", "naispoiss" või "meesnaine", mis võisid tähendada nii lesbit kui ka transsoolist meest. 1929. ja 1932. aastal ilmusid pikemad lood seadusega pahuksis olnud naistest, kes kandsid meeste riideid, kui olid püüdnud abielluda või käia teiste naistega. Samasooliste abielude näiteid leidus nii Tallinnast kui ka Saksamaalt (Esmaspäev 1929, Tallinna Post 1932).

Lesbide kohta ilmunud materjale on raske määratleda, sest hoolimata naiste ühiskondliku positsiooni murrangulisest muutumisest meestest sõltumatumaks esitati naiste homoseksuaalsust asjaolude kokkusattumusena (meeste rõivais naine oleks justkui häda sunnil naisega koos), patoloogiana (kriminaalsed ja avalikud naised ei tegevat vahet õigel ja valel soolisel käitumisel) või mindi 
homoseksuaalsuse võimalusest lihtsalt mööda (Tallinna Post 1932). Nii otsiti vanatüdrukuks nimetatud kehalise kasvatuse õpetajale Karinile tema venda portreteerivas loos meest (Eesti Spordileht 1930), samas kui teistes artiklites kajastati Karini plaane sõita koos sama ametit pidava ning pildil samasugust seelikut, kampsunit ja baretti kandva sõbranna Olliga jalgratastel Prantsusmaale ja tagasi ning soovi reisida rattaga ümber maailma (Ilmaränduritena 1928, Sakala 1928). Sellises kombinatsioonis on artiklites justkui välistatud võimalus, et nad olid omavahel romantilises suhtes.

Kvääride kogukondade efemeersusest ja varjatud kultuurist kirjutanud José Esteban Muñoz on välja toonud, et turvalisuse huvides oli varem ja mõnikord ka nüüdisajal oluline, et avalikus ruumis antakse vähemuste kultuurist ainult salamisi mõista, nii et vaid epistemoloogiliselt samasse gruppi kuulujad on suutelised täpselt mõistma, millest jutt (Muñoz 1996: 6). Seega kui võtta Olli ja Karini puhul lähtepunktiks lesbide subkultuur - kus samad kostüümid, sportlik eluviis, kahekesi maailma vallutamine on tavaks (Turner Carney 2018) -, ei ole ühtegi põhjust mitte pidada neid lesbipaariks, ning sellisel juhul näitab see juhtum lesbilisuse mahavaikimist, kus ees- ja perekonnanimedega naiste seksuaalsus on miski, mis on jäetud mainimata. Kodanikunime ja homoseksuaalsust mainiti koos ainult mõrvatud homoseksuaalsete meeste puhul (Esmaspäev 1928) või seoses rahvusvahelist tähelepanu pälvinud välismaalastega (Tallinna Post 1932).

Enamasti on raske öelda, kuidas soo ja seksuaalsuse kohta käivad sõnad täpselt kasutusele tulid, aga mõiste 'hermafrodiit' definitsiooniga 'meesnaine' leidus uue sõnana eesti-saksa keele tõlkimise artiklis 1918/1919 Eesti Kirjanduse kuukirjas (Ernits 1918: 89) ning “androgüün" ilmus õigekeelsussõnastikus 1925. aastal kui "meesnaisus, mõlemasugusus" (ÕS 1925: 15). Ajakirjas Eesti Arst arutati 1922. aasta numbris homoseksuaalsust käsitlevate raamatute üle (Lellep 1922: 142), kus kasutati ka hermafrodiidi sõna ning 1925. aastal kaitses W. E. Krause Tartu Ülikoolis doktoriväitekirja "Quantitative Untersuchungen über experimentellen Hermaphroditismus", milles käsitles suguorganite emasloomadelt isasloomadele siirdamise katseid merisigadel. Lisaks ilmus 1922. aastal tõlkeraamat "Suguelu tervishoid", millele oli üsna detailsete kirjeldustega lisapeatüki nii naiste kui ka meeste homoseksuaalsetest suguaktidest kirjutanud šveitsi arst Auguste Forel (Forel 1922: 85-103) ning 1925. aastal ilmus Elli Jägeri tõlkes raamat "Naise suguelu", kus feministlik kirjanik Johanna Elberskirchen kirjutas lesbilisusest kui ebatavalisest nähtusest, mida ei peaks hukka mõistma (Elberskirchen 1925: 206). Need teaduslikud ja populaarteaduslikud uurimused viitavad soolisuse teemast teadlikkusele nii humanitaarkui ka loodusteadlaste seas. Sellest hoolimata (või just sellest ajendatuna) on ajakirjandusest näha, et sõna "hermafrodiit" pälvis palju tähelepanu ja külvas 
(soo)segadust, kuna seda kasutati paralleelselt või vaheldumisi "androgüüniga" (Virumaa Teataja 1931).

Mütoloogias ja etümoloogiliselt tähendavadki mõlemad sõnad korraga mees- ja naissoo kehastamist, mille puhul 20. sajandil hakati kasutama mõistet “interseksuaalsus" (intersex) või vahesoolisus. Nagu Anne Fausto Sterlingi 1980-90. aastate uurimustööst hermafrodiitide kohta selgus, ei hõlma see mõiste piisavalt asjaolu, et bioloogiline sugu võib olla väga mitmekesine, kombineerides X ja Y kromosoome küllaltki suvaliselt, samuti ei pruugi nn vastassoo organid olla väliselt üldse nähtavad, elu jooksul üldse kuidagi ilmneda ning ka välisvaatlusel nähtavad suguorganid võivad oma kujult olla sobivad korraga nii mehele kui ka naisele (Fausto-Sterling 2000: 20). Diskursus, mis neid kahte mõistet meditsiiniliselt ja sotsiaalselt eristama hakkas, oli sõdadevahelisel perioodil alles kujunemas ning võtmeisikuks vähemusseksuaalsuste teaduslikus uurimises oli Eestis Berliini seksuoloog Magnus Hirschfeld.

Doktor Magnus Hirschfeldist kirjutati Eestis esmakordselt saksa keeles seoses 1907. aasta Eulenbergi afääriga (Kalkun 2020), aga eesti keeles esimest korda 1921. aastal seoses seksuaalreformi kongressiga Berliinis, kuhu kutsuti ka Tartu Ülikooli teadlased (Päevaleht 1921). 1924. aasta reportaaž käsitles Berliini dekadentlikku ööelu ning Hirschfeldi eksperimentaalset seksuaalkliinikut, kus uuriti kõikvõimalikke sugusid ja seksuaalseid sättumusi ning mille asukaid nimetati reportaažis inimesteks, kellel puudub sugu või kolmandast soost inimesteks (Esmaspäev 1924). 1928. aastal ilmus artikkel Protensi-nimeliselt autorilt, kes kirjeldas kokkupuuteid homoseksuaalsete meestega, mis seostusid tema käiguga 1921. aastal Berliinis avalikule koosolekule, kus Hirschfeld pidas ettekande, miks meestevaheline armastus tuleks dekriminaliseerida. 1929. aastal käis Hirschfeld Tallinnas ja Tartus avalikke loenguid pidamas ning ajalehed avaldasid mõlemast kokkuvõtte (Päevaleht 1929a, Päevaleht 1929b). 1928. aastal ilmus Hirschfeldi raamatu "Die Transvestiten" (1910) ainetel artikkel "Suguvõltsijad" ajaloost tuntud meheriideid kandnud naistest ja naiseriideid kandnud meestest. Kõigepealt ilmus artikkel Päevalehes ja Postimehes, paar aastat hiljem Rahvalehes ning väikese muudatusega uuesti 1935. aastal Tallinna Postis, kusjuures esimesed artiklid püüdsid hoida neutraalset tooni, hilisemad esitasid materjali sensatsioonilisemana (Päevaleht 1928; Postimees 1928; Rahvaleht 1930, 1931; Tallinna Post 1935).

1929. aasta Hirschfeldi loengu kuulutused, sh teadaanne, et Estonia saal on välja müüdud, ilmusid mõnikord kõrvuti reportaažidega Inglismaal aset leidnud Victor Barkeri looga, mis pälvis detailset kajastust. Artiklite vahendusel selgus, et "nais-meheks" nimetatud kolonel Barker oli sündinud Belgias naisena, olnud abielus kahe mehega ning tal oli kaks last. Kahekümnendates eluaastates hakkas Barker kandma meeste rõivaid ja abiellus naisega, kellega 
tehtud kohtuintervjuust selgus, et 33aastane naine sai alles ajalehest teada, et tema abikaasa, kellega tal oli olnud normaalne suguline läbikäimine, polegi tavaline mees (Kuidas abiellus 1929). Barker sattus avalikkuse tähelepanu alla, kuna ei läinud õigeaegselt oma ettevõtte pankrotti välja kuulutama, ning kui ta kinnipeetuna vanglas lahti riietati, leiti, et ta on bioloogiliselt naine, ning naisega abielludes oli ta seaduse silmis riiki petnud (Naine 1929; Vaba Maa 1929; Uus Eesti 1937). Barkeri loole järgnes hulk lugusid meheriietes elavatest naistest ja naiseriideid kandvatest meestest nii Riias, Californias kui ka Viljandis ja Tartus (Päevaleht 1932; Teine "kapten Barker" 1929; Viljandi Uudised 1929; Vaba Maa 1932).

Viimane välismaine suuremat tähelepanu pälvinud juhtum, mida Eesti ajakirjanduses korduvalt käsitleti, oli see, kuidas kunstnik Gertrud Wegeneri abikaasast Einarist sai maailma esimeste sookorrigeerimise operatsioonide läbi Lily Elbe. Elbele omistati heteroseksuaalsust, kui väljendati eeldust, et Lily ja Gertrud lahutasid oma abielu suhte lõppemise pärast, kuigi tegelikult lahutas nende abielu kohus, kuna samast soost inimeste abielu oli seadusega vastuolus (Järvamaa 1931; Sakala Pühapäev 1931; Sakala 1931a). Suur osa Lily Elbe muutumist käsitlevatest lugudest on tõlkeartiklid, mida ilmus tavaliselt pigem vähe. Need paistavad silma, sest lahkasid teemat kaasaelamise ja selgitavate kirjeldustega juriidilistest ja meditsiinilistest protsessidest, mida Elbe juhtum kaasa tõi. Elbe antud ütlused pärast operatsioone väljendasid rõõmu, et ta sai elada iseendana. Viimast korda mainiti Lily Elbet 1931. aasta sügisel, kui ta pärast järjekordse operatsiooni ebaõnnestumist suri (Sakala 1931b). Järgneval aastal ilmus paar usutlust arstidega sookorrigeerimise operatsioonidest, kuid 1933. aastast alates jäi kvääridest kirjutatud artikleid vähemaks ning seksuaal- ja soovähemusi käsitlevate lugude tonaalsus muutus konservatiivse poliitilise pöörde järel hukkamõistvaks (Eesti Naine 1934: 36; Eesti Naine 1935: 266) ning arutelud taandusid.

Teaduslikud ja sensatsioonilised artiklid olid mõnikord osa seadusandlust puudutavast diskussioonist, millest kirjutab homoseksuaalsete meeste kohtutoimikuid vaatlevas artiklis Andreas Kalkun (Kalkun 2018). Nagu eespool mainitud, sattusid end soonormatiivide suhtes vastuoluliselt väljendavad inimesed tihti krimiuudiste rubriiki, kus homoseksuaalsust rõhutati millegi patoloogilise või kriminogeensena. Sellistele eelarvamustele vastandus Magnus Hirschfeld, kes teadlasena seisis homoseksuaalsuse dekriminaliseerimise eest, kirjeldades seda sättumust küll ebatavalisena, aga mitte haigusena. 1926. aastal võeti Eestis vastu kriminaalseadus, mis ei keelanud täiskasvanud meeste vastastikusel kokkuleppel toimuvaid seksuaalakte. Seadus jõustus 1935. aastal (Uus Sõna 1935). Arstiteadlaste peetud kriminaalseadustiku teemalistes aruteludes põhjendati 1924. aastal toimunud koosolekul, et homoseksuaalsuse kriminali- 
seerimine toob kaasa rohkem väljapressimisi kui seksuaalroimasid, mistõttu on tõhusam konsensuslikke seksuaalakte mitte keelustada (Talvik 1925: 49).

1937. aastal ilmusid minu otsingute viimased seksuaal- ja soovähemusi käsitlevad lood, mis käsitlesid peatusid vähemusrühmadesse kuuluvate inimeste lugudel pikemalt kui juhuslik mainimine. Aprillis kirjutati, et kolonel Barker, kes pärast üheksakuust vangistust 1929. aastal oli leidnud tööd teenrina, sattus jälle kohtu ette, sedapuhku viie naela varastamise eest (Uus Eesti 1937). 1937. aasta septembri Vaba Maa andis teada, et Saksamaal võimule tulnud natsid olid Berliinis Magnus Hirschfeldi kliiniku ja seksuoloogia muuseumi sulgenud ja hävitanud. (Reinberg 1937) Sellega jõudis lõpule üks seksuaalküsimuste suhtes liberaalsem periood, mille jooksul Eesti avalikkuses seksuaal- ja soovähemusi kajastati. Kahe maailmasõja vahel ilmus veel hulk lühemaid nuppe, kus anti ülevaade suurlinnade dekadentsist, nagu Praha homoseksuaalne liikumine ja ajakirjad, habemega naised, lood liiga andekatest naissportlastest, keda kahtlustati vahesoolisuses (Suurlinna 1931; Eesti Spordileht 1934; Kaheldakse 1936), mees otsib meest tutvumiskuulutus (Vaba Maa 1925), lugejakiri naiselt, kes otsis naist, aga kelle tutvumiskuulutusi ei avaldatud ja toimetus soovitas naisel ikkagi mehele minna (Uudisleht 1931). Ometi osalesid ka need juhuslikumad lood kindlasti kaasa soolisuse ja seksuaalsuse tähenduse ja ajastu diskursiivse keskkonna loomises, kus nii enamusse kui ka vähemusse kuuluvad inimesed tahes-tahtmata elasid.

Ent veel kord: mida nende lugudega teha? Esiteks pole minu arhiivileiud tõenäoliselt ammendav kogum seksuaal- ja soovähemuste representatsioonidest sõdadevahelise Eesti meedias ning seepärast pean leppima sellega, et osa materjalist jääbki vähemalt siinses artiklis hoomamatuks. Seksuaal- ja soovähemuste aktivistlik liikumine on väärtustanud vähemuste avaliku nähtavuse suurendamise representatsioonipoliitikat. Aktivistliku representatsioonipoliitika plaanis tõestab minu leitud kogum, et sõdadevahelises Eestis toimusid diskussioonid seksuaal- ja soovähemuste üle. Sarnaselt rahvusvahelises LGBTQI+ ajalookirjutuses esitatud juhtumiuuringutega pole ülaltoodud lood tihti kuigi üheselt mõistetavad ega n-ö õnnelikud, vaid räägivad pigem vahelejäämistest, äpardustest ja homofoobia mitmesugustest ilmingutest, vähem aga vähemusse kuuluvate inimeste endi kogemustest. Teisalt, kui homofoobia kõrvale jätta, ei anna need ümberjutustused kuigi hästi edasi struktuurseid seoseid ühiskonnaga, millest need lood välja kasvasid. 


\section{Meesnaise A. Oinatski genealoogia}

Eespool tegin ülevaate sõdadevahelisel perioodil Eesti trükimeedias ilmunud seksuaal- ja soovähemusi puudutanud lugudest. Selles alapeatükis analüüsin aga ühte tuntuimatest eesti kvääridest, A. Oinatskit, kelle kohta ilmus aastatel 1929-1934 mõnikümmend artiklit, uudisnuppu ja kohtuistungireportaaži. Eugeenik Hans Madissoon pidas A. Oinatski kohta vähemalt ühe teadusliku ettekande, mis avaldati koos järelaruteluga arstide liidu ajakirja Eesti Arst kahes numbris. Lisaks olen tänu koostööle Vahur Aabramsiga leidnud A. Oinatski kohtuprotokollid ja teisi arhiivitoimikuid. Nende allikate põhjal on A. Oinatski seni ainus sõdadevahelise perioodi kväär Eestis, kelle omahäälne selgitus ristriietumisest (cross-dressing) tema kaasajal avalikult levis ning on artiklite, intervjuude, kohtutoimikute ja teiste arhiiviallikate kujul praeguseni säilinud ja kättesaadav. Tänu mitmekülgsetele allikatele on võimalik analüüsida A. Oinatski juhtumi genealoogiat Karen Baradi mudeli abil.

Eelnevast meediatekstide analüüsist ilmnes, et inimeste, kes polnud heteroseksuaalsed, kohta käivate sõnade tähendus ei olnud ajakirjanike ega teadlaste seas fikseeritud, mõisted 'homoseksualist', 'naismees' ja 'meesnaine' võisid, aga ei pruukinud olla kasutusel sünonüümidena. Nagu on kirjutanud USA transsoolisuse ajaloolane Susan Stryker, mõtestati tööstusrevolutsiooni perioodil, mil seksuaal- ja soovähemuste kogukonnad linnastumise käigus tekkisid, meeste homoseksuaalsust soolise äraspidisusega ehk sooviga olla naine ning naiste homoseksuaalsust sooviga olla mees (Stryker 2017: 50). Samal perioodil ilmus USA ajakirjanduses pidevalt lugusid ristriietujatest ehk meheriietes naistest ja naiseriietes meestest (Stryker 2017: 48) ning mõisted homo- ja heteroseksuaalsus olid alles nii uued, et nende tähendusega täitmise protsess oli paljude sajandivahetuse teadlaste, sh psühhiaatrite, kirurgide, günekoloogide ja eugeenikute elutöö (Stryker 2017: 52-54).

Ka Eesti ajakirjanduses ilmus palju artikleid ristriietujatest. Mõned neist ilmusid uudisnupuna isevärki külaelanikest või kohtukaasustest, kus paarid lahutati, kui selgus, et üks partner on vahesooline, aga bioloogiliselt pigem samast soost teise abikaasaga. Enamik ristriietumist jutuks võtvaid artikleid ilmus krimiuudiste rubriikides, kus meheriietes naised, kes võisid olla ka lesbid, kuulutati tuntud varasteks või olid meesvargad end naiseks riietanud (ristriietumine Eestis seadusega keelatud polnud). Erandlik juhtum on "meesnaine" A. Oinatski, kes oli aastatel 1929-1934 pidevalt Eesti ajakirjanduse huviorbiidis pärast seda, kui oli eri naisenimede all esinemise eest karistada saanud ja hiljem mitmete vargustega seoses uurimise alla ja vangi sattus, kuni 1934. aastal avalikkusest kadus, kohtutega enam kokku ei puutunud ning elas ENSVs silmapaistmatult. Nii on A. Oinatski juhtum genealoogiliselt uurimi- 
seks väga sobiv aines, kuna tema avalikkuseni ulatuv elu on ajaliselt ja seega sisuliselt juba materjalidest lähtuvalt piiratud, mis võimaldab tähenduslike seoste põhjal ajutistegi üldistuste tegemist.

Kokku olen A. Oinatskist leidnud aastatest 1929-1934 umbes 25 originaalartiklit, millele on lisandunud hulgaliselt kordustrükke teistes sama nädala või kuu väljaannetes. Enamik artikleid toetus A. Oinatski politseitoimikutele, mis olid sel perioodil nähtavasti ajakirjanikele vabalt kättesaadavad. Ülejäänud artiklid ja nupud andsid ülevaateid A. Oinatski kohtuistungitest või menetluses olevates kahtlustustest. Ühes esimestest artiklitest, Postimehes avaldatud A. Oinatski fotoga persooniloos "Tütarlaps, kes kavatseb naist võtta", tutvustati A. Oinatskit Eesti oma kolonel Barkerina, kellest sama aasta kevadel oli palju kirjutatud (Tütarlaps 1929). Pikk artikkel andis ülevaate A. Oinatski senistest seadusvastastest tegudest, tema "kalduvusest olla naisterahvas" ning sellest, kuidas ta on end korduvalt eri naisenimede all tutvustanud. Nimelt selgus, et A. Oinatski oli lapsest saati eelistanud naiste riideid ning pärast kaks ja pool aastat koolis käimist oli ta kasvatanud juuksed pikaks ja teeninud mitmetes taludes tüdrukuna, nii et keegi ei osanud kahtlustagi, et tegemist võiks olla mehega. Artiklis mainitakse, et esmakordselt sattus A. Oinatski kohtu alla 15aastaselt, kui ta oli tööandjalt varastanud naisterõivad, kuid jäänud oma nooruse tõttu karistamata, artikli lõpus seletatakse 20aastase noormehe esinemist 27 aastase naisena sooviga hoida kõrvale sõjaväest. A. Oinatski fotoga artikli lõpus kirjeldatakse tema välimust, häält, juukseid, roosat kleiti ja figuuri selgete naiselikkuse ilmingutena. Artikli lõpus küsiti A. Oinatskilt, kas tal on kavas sõjaväkke minna ja ka naist võtta, mille peale A. Oinatski vastas jaatavalt ja hakkas nutma (Tütarlaps 1929).

Informatsioon A. Oinatski kohta on küllaltki vastuoluline, esiteks seetõttu, et ta püüdis varjata politsei eest oma sünnikohta ja perekonda, teiseks kuna ta kujunes omalaadseks exemplumiks, kelle kohta ajakirjandus võis osa infot ka välja mõelda või millegi põhjal tuletada, sest lugejahuvi tema vastu oli nähtavasti suur. Aja jooksul kasutas A. Oinatski ise ja tema kohta kasutati ligi kümmet nime - võiks isegi öelda, et nimedega A. Oinatski kõige rohkem sobi tegigi - ning sellepärast kasutan siingi täpsuse mõttes vaid tema eesnime initsiaali ja perekonnanime. Kohtutoimikutest selgub, et A. Oinatski sündis 1906. või 1908. aastal Lõuna-Eesti talutööliste peres. See pere liikus seoses tööga peamiselt Tartu ja Võru maakondades. Eri allikate andmetel (politsei intervjuud A. Oinatski, tema ema ja koguduse preestriga) oli A. Oinatski eelistanud lapsest saati naiseriiete kandmist (ERA.1947.3.3142, ERA.1947.3.3095). Mõne artikli põhjal võib arvata, et A. Oinatski lahkus või põgenes pere juurest 15aastasena ega olnud ema mitu aastat näinud, enne kui too last politseisse tuvastama kutsuti, seejuures väitis A. Oinatski algul, et ei tunne teda (Mees 
1929, Tütarlaps 1929). Paari juhtumiga seoses tuli jutuks A. Oinatski käimine kirikus, kus teda peeti ühemõtteliselt naiseks (Naiseriides 1930).

1932. aastal kirjutati ajalehtedes, kuidas 21aastane talusulane Osvald soovib kosida A. Oinatskit, kes olevat noormehe kaasavara-lubadusega ära petnud. Seda kujutati teatava järjena A. Oinatski varasematele pettustele, kui ta oli temaga abielluda lubanud meestelt väärisesemeid varastanud (Meesnaine 1929; Osvald 1932). A. Oinatski luhtunud abiellumissoov polnud sel perioodil ainus kvääride abiellujate lugu: 1925. aastal kirjutati Karksis elanud naisest ja vahesoolisest, kellel kirik ei lasknud omavahel abielluda (Karksis 1925), 1929. aastal kirjutati Victor Barkeri ja 1931. aastal Lily Elbe abielude tühistamisest kohtu poolt. 1933. aastal, s.o aasta pärast A. Oinatski juhtumit, kirjutati Lätis Valkas elanud nelja lapsega abielupaarist, kus pereisa kuulutati kohtus naiseks, abielu tühistati ja lapsed jäeti vaeslaste staatusse (Kui mees 1933). Paar nädalat hiljem kirjutati sellest, kuidas Rumeenia kolonel, kes oli teadmatusest abiellunud transsoolise naisega, abielu lahutas (Meeste abielu 1933). Pikemalt kirjutati meeste pulmapidudest ja neid laulatanud preestrist artiklisarjas "Lilla õudus" (Lilla õudus 2.XII 1933). Eelmainitud artikleid üldistavalt hinnates järeldan, et abiellumist ja pere loomist peeti inimeksistentsi niivõrd endastmõistetavaks normiks, et kui ka samasooliste abiellumist võimalikuks või kõlbeliseks ei arvatud, võeti abiellumise soovi siiski millegi loomulikuna ning mõnel puhul, nagu ka 1929. aasta A. Oinatski intervjuust paistab, pakuti kväärile lahendusena bioloogilisest vastassoost partneri otsimist.

Aastatel 1929-1934 ilmus A. Oinatski suuremate ja väiksemate, toimunud ja kahtlustatavate varguste kohta nii pikemaid kui ka lühemaid uudisnuppe, millest selgub, et ta varastas mitu korda oma endistelt tööandjatelt, kelle juurest ta oli põgusalt töötamise järel ootamatult kadunud. Viimast korda karistati A. Oinatskit 1934. aastal kanga varastamise eest oma endiselt tööandjalt, reportaažid kohtuistungilt kirjeldasid A. Oinatskit vurrudega naisena, sest A. Oinatski, ehkki vuntsid ajamata ja meheriided seljas, rääkinud siiski kõrge häälega ja käitunud naise moodi (Vurrudega 1934). Rohkem A. Oinatskist kui meesnaisest ajalehtedes ei kirjutatud. Nimemuutjate rubriigist käis läbi keegi, keda võib pidada A. Oinatskiks ja kes hiljem elas Nõukogude Eestis mitukümmend aastat kuni oma surmani seaduskuulekat elu.

Kui A. Oinatski 1929. aastal esimest korda arestimajja sattus, otsustati politseis meditsiinilise ülevaatuse abil välja selgitada A. Oinatski bioloogiline sugu. Pikemalt uuris ja mõõtis A. Oinatskit 1924. aastal asutatud Eesti Eugeenika Seltsi “Tõutervis” eestvedaja, kohtumeditsiini arst Hans Madisson (pärast nimemuutmist 1935. aastal Madissoon), kes esitas A. Oinatski profiilis alastipildiga illustreeritud eugeenilise uurimuse 1931. aasta ajakirja Eesti Arst 12. numbris ning kelle ettekande kokkuvõtteid ajalehtedes kajastati. Neis kajastustes esi- 
tati lühidalt A. Oinatski elulugu, loetleti kuriteod ja anti mõned mõõdud, mis viitasid tema naiselikkusele, samas mööndes, et günekoloog R. Kleitsmann ei tuvastanud sisemisi naissuguorganeid, mistõttu Madissoni hinnangul polnud A. Oinatski hermafrodiit, vaid n-ö funktsioneeriv mees naiseriietes (Meesnaine 1931; Oma Maa 1931; Madisson 1931: 663-664). Hans Madissoni artiklile järgnes Eesti Arsti järgmise numbri arutelu rubriigis kommentaar Gerhard Rooksilt, kes oli A. Oinatski läbi vaadanud enne Madissoni, ning pakkus, et A. Oinatski võis olla teist tüüpi vahesooline kui see, mille Madisson oma diagnoosis välja pakkus (Rooks 1932: 505-506).

Kokkuvõttes põhjendas Hans Madisson A. Oinatski kalduvust kuritegevusele "hingelise degeneratsiooniga", mis pärinevat tema väidetavalt kontrollimatu vihaga isalt ja hullumeelselt isapoolselt vanaemalt, ning mis avaldunuvat "iseäranis tugevalt suguelu diferentseerimatuses. Oinatskil puudub selgejooneline sugupoole instinkt. Kui teda võib uskuda, siis armastab ta mehi, armub neisse. [---] Siiski ei põlga naisi, riietub naisena, otsib nende seltskonda [---] naisterahva riiete järele on tal otse haiglane iha" (Oma Maa 1931). Seega otsis Hans Madisson A. Oinatskit uurides tõendeid, et tegemist on "füüsilises mõttes ebanormaalselt arenenud" ja "vaimselt alaarenenud inimesega", mitte hermafrodiidiga (Madisson 1932: 674). Eugeenik kirjeldas A. Oinatskit mehest mõõtude poolest alaväärsemana, seejuures olevat A. Oinatski pikkus ja aju olnud keskmise eesti naise mõõtu, kõik A. Oinatski välised suguorganid aga olnud funktsionaalse mehe omad. Tõestuse esitamises selle kohta, et A. Oinatski on pärinud oma sugulise ebanormaalsuse isaliinis, nägi Hans Madisson, - kes 1928. aastast kuni Teise maailmasõjani "Tõutervise" eestvedajana propageeris erinevate n-ö alaväärsete sundsterilisatsiooni - olulist argumenti. Madisson pidas seksuaalkurjategijate ja vaimuhaigete steriliseerimist kuluefektiivsemaks kui nende isoleerimist (Madisson 1927: 311), seejuures käsitles ta ka homoseksuaalsust kurikalduvusega sugutungina (Madisson 1927: 320). Madisson polnud siiski nii autoriteetne kui need arstid (eesotsas Magnus Hirschfeldiga), kes pidasid hermafrodiite vaimselt normaalseteks, kehaliselt ebatavalisteks inimesteks, kellel tuleks lasta vabalt elada, mitte kriminaliseerida nende suguakte (Protens 1928).

Nagu Eesti eugeenika ajalugu uurinud Peeter Tammeveski, Leiu Heapost ja Ken Kalling on kirjutanud, oli Eesti eugeenikaliikumine enamjaolt siiski pigem pronatalistlik ja kuulutas ette rahva väljasuremist kui nn negatiivse eugeenika ehk steriliseerimise meelne (Tammeveski 2005: 11; Kalling \& Heapost 2007: 254). Seda tõestavad mitmed seltsi välja töötatud iibetõstmise meetmed abordi kriminaliseerimisest lastetuse maksustamiseni (Mäelo 1926; Mäelo 1935: 39). Teisalt muutusid Teise maailmasõja eel diskursus ja seadused, sest 1937. aastal jõustus Eestis sundsteriliseerimise seadus, mille rakendamisel steriliseeriti 
kahe aasta jooksul 41 inimest. Neist 37 olid naised, kellest osa sundsteriliseeriti veel abordi käigus (Kalling 2007: 256). Samal aastal kirjutas Madissoni kolleeg August Viidik sundsteriliseerimisest mujal Euroopas, tuues eeskujuks Taani, kus homoseksuaalsust peeti roimaks ja nõdrameelsuse kaassümptomiks (Viidik 1937: 75).

Vajadus Eesti rahva tõutervist rahvusluse nimel parandada tekkis vastureaktsioonina väidetele, et eestlased on mongoliidse rassi esindajad (Kalling \& Heapost 2013: 86), keda peeti valgest rassist alamaks (Gould 1996: 85-88). Samal ajal oli eugeeniline rassism suurtes lääneriikides väga populaarne rahvastiku regulatsiooniteooria, mis viis holokaustini, kus rassipuhtuse nimel tapeti juute, romasid, LGBT-inimesi, psüühikahäiretega inimesi (Heineman 2002: 23). Niisiis oli eugeenika Eestis omamoodi moodne nähtus, mille toel püüti vastanduda Nõukogude Venemaale, näitamaks, et Eesti inimesed erinevad sealsetest rahvastest geneetiliselt (Kalling 2007: 254). Sundsteriliseerimise keelustas Nõukogude okupatsioon, mis pidas steriliseerimist amoraalseks (Tammeveski 2005: 12; Kalling 2013: 54).

Nagu rassi- ja soouurija Siobhan Somerville 1994. aastal näitas, sündisid mõisted "rass" ja "homoseksuaalsus" enam-vähem üheaegselt ning 19. sajandi keskpaigast alates hakkasid paljud riigid ellu viima Michel Foucault' sõnastatud biovõimu, paigutades inimeste kehad rassi ja seksuaalsuse mõistete toel riigi võimu ja reproduktiivpoliitika kontrolli alla (Somerville 1994: 244). Karen Baradi agentse realismi mudelis tuleks niisiis meesnaist A. Oinatskit kui genealoogiliselt materiaal-diskursiivsete praktikate läbi seotud suhtlusvõrgustikus (entangled) asetsevat nähtust nimetada rahvapäraselt androgüüniks ja hermafrodiidiks, mis sõnaraamatutes tõlgiti “meesnaiseks". Meesnaise tähendus rakendus intra-aktiivses materiaal-diskursiivses praktikas, kus hermafrodiit oli meditsiiniline nähtus, mida allutati eugeeniliselt meditsiiniteaduse juhatusel, ajakirjanduse vahendusel ning seadusandluse ja kohtu toel rassipuhtuse ja rahvusliku saavutuse eesmärgile. A. Oinatski sattus kõigi nende institutsioonide tähelepanu keskpunkti ning ilmus ikka ja jälle artiklites jutuks kui teada-tuntud meesnaine, korduvalt kinnipeetud ja karistatud kriminaal, kelle sugu ja seksuaalsus olid nii Eesti seaduse kui teaduse silmis ebanormaalsed, ülekontrollimist ja läbiuurimist vajavad. Ent nii nagu mõjutasid seadused ja meditsiinilised läbivaatlused A. Oinatski subjektsust, samamoodi mõjutas A. Oinatski loo avalikkus arusaama sellest, milline võiks üks meesnaine õigu poolest olla, mismoodi välja näha ja kuidas elada nendes tingimustes, mille ühiskondlik kokkulepe oli loonud.

Võib öelda, et kui jätta kõrvale ajakirjanduse kommertshuvidele omane kõmuline ja meelelahutuslik tahk, rakendati A. Oinatski persoon Eesti eugeenilise marurahvusluse tööriista rolli, kelle näidet kasutati ettekannete ja ajalehear- 
tiklite vahendusel avalikkuse teavitamiseks, et homoseksuaalsus (suguline ebanormaalsus) ja vahesoolisus (hermafroditism) on hälbed, mis rahva tervist ja rassilist kooslust ohustavad, kuna ei täida reproduktsiooni eesmärki (Kukke 1935: 102). Tugeva tervisega rahvast oli jällegi tarvis riigikaitse huvides nii koloniaalsete suurriikide vägivalla kui ka kestmajäämise hirmus (Eesti rahva tulevik II 1935). Neid hirme kasutati omakorda ära, seades avalikkust silmitsi intiimsete detailidega A. Oinatski elust kui exemplumist, jättes ta nagu hoiatuseks ilma vähimastki isiklikust ruumist, rääkimata valikuvabadusest, kuidas end sooliselt väljendada.

\section{Kokkuvõte}

Kui Anna-Stina Treumundi fotosari visualiseeris naisajaloo nähtamatuse ja üldises ajalooteadmises olevat lünka, s.o seda, et me ei tea just palju sajandi eest või enne seda elanud kuulsatest ega tundmatutest naistest, siis käesolev artikkel püüab pakkuda mõningaid põhjendusi, miks püüti jääda nähtamatuks. Kõige paremini selgitab nähtamatuse eesmärki meesnaise A. Oinatski juhtum, kes võõrandati omaenda kehast, teda avalikult lahti riietades ja tema suguelundite üle pikalt arutledes. Sellise normatiivsusest erinemise groteskse kujutamise hirmus võisid paljud inimesed teha kõik endast oleneva, et mitte sattuda avalikkuse tähelepanu alla ning tõenäoliselt püüdsid ka kõik ülejäänud ühiskonnaliikmed sarnast olukorda targu vältida.

Olen oma artiklis püüdnud välja joonistada sõdadevahelise perioodi Eesti kvääre, s.o seksuaal- ja soovähemusi puudutavaid lugusid, nii nagu need ilmnesid ajakirjanduses, seksuaaltervise käsitlustes ja meditsiiniajakirjanduses. Leidsin lugusid geide subkultuurist ja mõrvadest; transsoolistest kui sensatsioonist, teadussaavutusest, pettustest; ristriietujatest ja lesbidest, kellest kirjutati peaaegu ainult seoses kuritegevusega või nende seksuaalsusest kui millestki valikulisest. Nii joonistusidki seksuaal- ja soovähemuste representeerimisel kõige olulisemate diskursustena välja ajastu meelelahutus ja kultuur (kino, kirjandus, kunst), meditsiiniteadus ja seadusandlus. Valdav osa ajakirjandusest leitud tekstikorpusest on niivõrd laialivalguv, et seksuaal- ja soovähemuste kohta nende põhjal eraldi on küllalt raske üldistusi teha. Niisiis sobis eri diskursuste paljususest lähtuvalt A. Oinatski juhtumiuuringuna analüüsimiseks ja tema kohta leitud materjali struktureerimiseks Karen Baradi feministlik teadusajaloo analüüsiks loodud agentse realismi teooria, mis rõhutab erinevate elementide vastastikuseid seoseid ja konteksti rolli tähendusloomes materiaaldiskursiivsete praktikate kaudu. Agentse realismi analüüsi toel leidsin, kuidas mõjutas eugeenika diskursus seksuaal- ja soovähemuste kujutamist sõdadeva- 
helises Eestis, ning kuidas see omakorda positsioneeris Eesti rahvusvahelise teaduse kontekstis, kus eugeenika oli väga populaarne teadusharu.

Kõige selgemalt tulid need seosed välja A. Oinatski juhtumi juures, kes oli kõige sagedamini mainitud kohalik kväär sõdadevahelisel perioodil Eestis. A. Oinatski lugu mõisteti seoses rahvusvahelist tähelepanu pälvinud transsooliste inimeste lugudega, mis ajakirjanduses teiste seksuaal- ja soovähemusi käsitlevate lugude kõrval sel ajal regulaarselt ilmusid, ning ka Eesti eugeenikud ja arstid võrdlesid teda teiste riikide arstide uurimustega. Kuigi kvääride inimeste endi häält on uuritud allikates vähevõitu, võib siiski öelda, et seksuaal- ja soovähemustest sõdadevahelises Eestis teati ja räägiti. Nende elu ja tegevuse kohta väljendati mitmesuguseid arvamusi ning avalikkuse ette jõudsid seadustega rohkem vastuollu läinud inimesed, kellel ei õnnestunud jääda nähtamatuks, samas mainiti ja võeti jutuks ka teisi "niisuguseid". See tähendab, et suurem osa meie kvääriajaloost jääbki paratamatult saladuseks, aga arhiividest võib tõenäoliselt leida kõnekaid fragmente, mille vahendusel paraneb meie teadmine sellest, kuidas inimesed kujundasid teadlikult oma elu ja tegevust heteronormatiivses kultuuris, kus homoseksuaalsus, transsoolisus ja vahesoolisus olid ühtaegu patologiseeritud ja sellessamas kultuuriproduktsioonis üsna tavaline nähtus.

\section{Tänuavaldused}

Artikkel on edasiarendus 26. oktoobril 2018 Tallinnas peetud ettekandest seminaril "Re-writing the past: LGBT+ history of the Baltics", mida toetas Rosa Luxemburgi fond. Teoreetiline raamistik on kirjutatud vahetusstuudiumi perioodil California ülikoolis Santa Cruzis. Uurimisloo alapeatükk põhineb 15. märtsil 2019. aastal toimunud seminaril “20. sajandi alguse Eesti kväärimine" peetud ettekandel Eesti Kirjandusmuuseumis. Tänan juhendajaid, samuti Vahur Aabramsit, Aet Kuusikut ning retsensente toetava ja konstruktiivse tagasiside eest kirjutamise mitmes järgus!

\section{Arhiiviallikad}

\section{Eesti Kirjandusmuuseumi Eesti Rahvaluule Arhiivis}

ERA.1947.3.3142

ERA.1947.3.3095 


\section{Digiteeritud ajalehed ja ajakirjad}

Eesti Naine 1934 = Mina ja sugukond (järjejutt). Eesti Naine 2, lk 34-37.

Eesti Naine 1935 = Mehe võitlus. Ka naine olgu teadlik selles (Peatükk [Arthur Herbert Gray] raamatust "Mees, naine ja Jumal. [Seksuaalküsimusi lähtudes kristlikult seisukohalt]”, tlk Salme Klaos). Eesti Naine 9, lk 262-266.

Eesti Spordileht 1930 = Killip, Juh[an] 1930. Meie sääremarja mehed. Eesti Spordileht 9,1 . märts, lk 7 .

Eesti Spordileht $1934=26$ aastaga 1.35st 1.05.4-ni. Eesti Spordileht 12, 18. detsember, lk 293-294.

Esmaspäev 1924 = Inimesed, kel puudub sugu. Esmaspäev. Piltidega nädalaleht 9, 3. märts 1924 , lk 6 .

Esmaspäev 1928 = Surmahoop kaikaga. Noorsõdur tappis kõlvatu kallaletungija. Homoseksualisti laip lennuväe lasketiirul. Esmaspäev. Piltidega nädalaleht 26, 25. juuni, lk 1.

Esmaspäev 1929 = Naine seaduse kammitsais. Esmaspäev. Piltidega nädalaleht 18, 6. mai, lk 8 .

Geenius-hull 1929 = Geenius-hull. Enamus geeniustest - homoseksualistid. Missugused olid nad inimestena. Uudisleht 68, 28. august, lk 6.

Ilmaränduritena 1928 = Eesti naissportlased ilmaränduritena. Postimees 173, 29. juuni, lk 5 .

Järvamaa 1931 = Mees muutus naiseks. Järvamaa põllumeeste, asunike ja väikemaapidajate häälekandja 31, 17. märts, lk 4.

Jõeäär 1926 = Jõeäär, A[leksander] 1926. Avalik kiri pr. Helmi Mäelole. Päevaleht 344, 18. detsember, $1 \mathrm{k} 4$.

Lilla õudus 1933 = Lilla õudus. Rahvaleht 106-120, 21. november -23 . detsember, lk 5/5-6.

Kaheldakse 1936 = Kaheldakse olümpia naisvõistlejate ehtsuses. Uus Eesti 217, 13. august, lk 2 .

Kaja 1929 = Armastuse eksiteed. Seksualiteet ja kriminaliteet. Prof. Magnus Hirschfeldi teiselt loengult. Kaja 104, 5. mai, lk 8.

Karksis 1925 = Woodewäli, Lembit 1925. Karksis kaks neiut abielluda tahtnud. Sakala 1, 3. jaanuar, lk 3 .

Kivikas, Alb[ert] 1928a. Kolm novellisti. Ülevaade III. August Gailit: "Ristisõitjad". Johannes Semper: "Sillatalad" ja "Ellinor". Mihkel Järva: "Tavalised". Postimees 5, 6. jaanuar, lk 4 .

Kivikas, Alb[ert] 1928b. Vastuseks Johannes Semperile. Postimees 7, 8. jaanuar, lk 2.

Kivikas, Alb[ert] 1928c. Johannes Semperi mõjutajad. Lisandusülevaade III. Postimees 19, 20. jaanuar, lk 4-5. 
Kivikas, Alb[ert] 1928d. Lõppnaljaks Johannes Semperile. Postimees (23) 24. jaanuar, lk 4 .

Kui mees 1933 = Kui mees tunnistatakse naiseks. Päevaleht 313, 16. november, lk 4.

Kuidas abiellus 1929 = Kuidas abiellus "kolonel" Barker. Päevaleht 116, 1. mai, lk 7.

Madisson, Hans 1931. Perversse sugukalduvusega isikuid. Eesti Arst 12, lk 663-674.

Mees 1929 = Mees viis aastat naisena. Oma Maa 94, 15. august, lk 2.

Meesnaine 1929 = Meesnaine osutus vargaks. Postimees 304, 8. november, lk 3.

Meesnaine 1931 = Meesnaine viie nime all. Arsti uurimus Alfred Oinatski üle. Kehaliselt mees, vaimliselt naine. Postimees 71, 13. märts, lk 1 .

Meeste abielu 1933 = Meeste abielu. Saaremaa Teataja. Maapidajate häälekandja 137, 30. november, lk 4 .

Mäelo, Helmi 1926. Nõuame rohkem arvestamist rahva ja riigiga. Kas karistust suguvilja hävitamise eest ära jätta? Päevaleht 329, 3. detsember, lk 2.

Naine 1929 = Naine kuus aastat koloneli osas. Oli sõjaväe poksiõpetaja, suitsetas ja jõi keskpärasest mehest rohkem. Päevaleht 71, 13. märts, lk 5.

Naiseriides 1930 = Naiseriides lehmavaras. Tartu-Võru rahukogu mõistis ta 8 kuuks vangi. Kaja 23, 28. jaanuar, lk 5 .

Naisterahva Elu 1925 = Thea Malten (pseudonüüm) 1925. Garçonne ja meesnaine. Naisterahva Elu 9, lk 8.

Oma Maa 1931 = Alfred-Liisa Oinatski. Huvitavaid jooni Tartu vanglas istuvast Oinatskist. Oma Maa 30, 14. märts, lk 4.

Osvald 1932 = Osvald tahab kosida Alfredi. Meesnaine Oinatski meelitas sulase ära. Postimees 84, 12. aprill, lk 2.

Postimees 1928 = Soovõltsijad. Kui mehed tahavad olla naised, ja ümberpöördult. Postimees 43, 13 veebruar, lk 5.

Protens 1928. Homoseksualistid meil ja mujal. Komblus langeb, homoseksualism levineb. Uudisleht 70, 19. september, lk 5.

Päevaleht 1921 = Ülikooli teated. Rahvusvaheline seksuaal-reformi kongress, kuhu ka Tartu ülikooli esitaja kutsutakse. Päevaleht 211, 12. august, lk 5.

Päevaleht 1928 = Soovõltsimised. Mehed, kes tahavad olla naised, ja naised, kes tahavad olla mehed. Päewaleht 36, 6. veebruar, lk 3 .

Päevaleht 1929a = Suguelu päevaküsimusi. Päevaleht 118, 3. mai 1929, lk 4.

Päevaleht 1929b = "Armastuse eksiteed". Prof. dr. med. Magnus Hirschfeldi teine loeng. Päevaleht 119, 4. mai, lk 4.

Päevaleht 1932 = Riia nais-mehe naine ei ole nõus abielu tühistamisega. Päevaleht 52, 22. veebruar, lk 3 .

Rahvaleht 1930 = Inimese soo võltsijad. Inimesed, kes armastavad kanda vastassoo riideid. - Soovõltsijad ja kriminalistika. - Ajaloolised transvestiidid - paavst Johanna, chevalier d'Eon, kuninganna Kristiine ja Orleani neitsi. Rahvaleht 82, 15. juuli, lk 5. 
Rahvaleht 1931 = Naised mehe riietuses. Püksseelik jälle päevakorral. - Ajaloolised naised, kes põlgasid oma sugupoolt. Rahvaleht 48, 25. aprill, lk 5.

Reinberg, K. 1937. Kontvõõrana Saksa Mihkli juures. Vaba Maa (256) 6. november, lk 8. Rooks, Gerhard 1932. 351 Arutlus. Eesti Arst 9, lk 505-506.

Sakala 1928 = Tallinna neiud jalgratastel ilmareisile. Sakala 75, 21. juuni, lk 4.

Sakala 1931a = Kuidas mehest sai naine. Hermafrodiit normaalinimeseks. Sakala 32, 17. märts, lk 7 .

Sakala $1931 \mathrm{~b}=$ Mehest tehtud naine suri. Sakala 108, 19. september, lk 1.

Sakala Pühapäev 1931 = Mees naiseks ja naine meheks. Sakala Pühapäev. Sakala kaasanne 13, 29. märts, lk 3 .

Semper 1928a = Semper, J[ohannes] 1928. Avalikke küsimusi. A. Kivikale kui arvustajale. Postimees 7, 8. jaanuar, lk 2.

Semper 1928b = Semper, J[ohannes] 1928. Vastuseks A. Kivikale. Postimees 9, 10. jaanuar, lk 5 .

Suurlinna 1931 = Suurlinna hukutavad mülkad. Tshehhoslovakkias võideldakse tagajärjetult prostitutsiooni vastu. Sakala 82, 21. juuli, lk 7 .

Tallinna Post 1932 = Ma ei taha olla naine. Inimesed, kes pole rahul oma sooga. Meie mees-naised ja nais-mehed. Tallinna Post 35, 28. august, lk 5.

Tallinna Post 1935 = Mehed naise, naised mehe rüüs. Vastassugupoole riietuse eelistajad. - On see haigus või harjumus? - Kuninganna Kristine ja Orleani neitsi olid transveriidid. Tallinna Post 22, 31. mai, lk 3.

Talvik, Siegfried Ferdinand 1925. Kohtulikarstiteaduslised märkused Eesti kriminaalseadustiku kava kohta. Eesti Arst. Lisa. Kolmas Eesti Arstidepäev Tallinnas 12. septembril 1924. Protokollid. Tartu 1925, lk 46-49.

Teine "kapten Barker" 1929 = Teine "kapten Barker". Veel üks naine abielumehena. Kaja 109, 11. mai, lk 4.

Tütarlaps 1929 = Tütarlaps, kes kavatseb naist võtta. Tartu kriminaal-politsei paljastas kummalise võltsimise. Alma Saar osutus Alfred Oinatskiks. Postimees 219, 15. august, $1 \mathrm{k} 6$.

Uudisleht 1931 = Elulised küsimused. Südame palve sinule. Uudisleht 143, 12. detsember, lk 12 .

Uus Eesti 1937 = Kolonel, kes on naine. Ühe inglanna kummaline elukäik. Uus Eesti 105, 18. aprill, lk 8.

Uus Kosjaleht 1932 = O.R. 1932. Pealinna öiseid varjukülgi. Uus Kosjaleht (4), lk 11-12

Uus Sõna 1935 = Juder (?) 1935. Mida toob “seaduste jüripäev"? Muudatusi kriminaalseadustes. Uus kriminaalseadustik karistab tööpõlgamise pärast ümberhulkumist. Abielurikkumine pole karistatav. Uus liik seksroimi. - Varguse ja riisumise mõiste ühendamine. Uus Sõna 7, 9. jaanuar, lk 2.

Vaba Maa 1925 = Meest otsib meest! Vaba Maa 117, 22. mai, lk 5. 
Vaba Maa 1929 = 9 kuud vangistust nais-mehele. Naine kuulis mehe naissoost ainult ajalehtedest. "Kolonel Barkeri" loo viimane vaatus. Vaba Maa 100, 1. mai, lk 7.

Vaba Maa 1932 = Rebaste "lend" pisargaasi ja politseiga. Naiste riietes meesüliõpilased konvendi hoonet piiramas. Politsei viis kirju seltskonna jaoskonda. Vaba Maa 99, 28. aprill, lk 1 .

Viidik 1937 = Viidik, August 1937. Steriliseerimisseaduste teostamisest välismail. Eesti Arst. Lisa. Eesti arstidepäev Viljandis 21.-22. augustil 1937. Protokollid. Tartu, lk 73-78.

Viljandi Uudised 1929 = Meesnaised ja naismehed Viljandis. Viljandi Uudised 42, 5. juuni, lk 3 .

Virumaa Teataja 1931 = Lätis leiti hermafrodiit kahe peaajuga. Virumaa Teataja 41, 14. aprill, lk 1.

Vurrudega 1934 = Mees-naine Võrus kohtus. Vurrudega naine meeste riietes. Võru Teataja 44, 24. aprill, lk 1.

Võru Teataja 1928 = -puu 1928. Johannes Semperi “Ellinor”. Võru Teataja 12, 31. jaanuar, $1 \mathrm{k} 2$.

Zirk, H. 1934. Miks vajab tänapäeva naine kehakultuuri? Tee ilule, tervisele ja noorusjõule. Eesti Spordileht 3, 1. märts, lk 58-60.

\section{Suulised allikad}

Kuusik, Aet 2018. LGBT March in Estonia - Past and Present Struggles. Seminaril "Re-writing the past: the LGBT+ history of the Baltics" 26.10.2018 EPIKojas peetud ettekanne (avaldamata).

Lember, Uku 2018. Male homosexual experiences in late Soviet Estonia through oral histories (first notes). Seminaril "Re-writing the past: the LGBT+ history of the Baltics" 26.10.2018 EPIKojas peetud ettekanne (avaldamata).

Ross, Johanna 2019. Lesbid ja androgüünid 20. sajandi eesti kirjanduses. Seminaril “20. sajandi alguse Eesti kväärimine” 15.03.2019 Eesti Kirjandusmuuseumis peetud ettekanne (avaldamata).

Stahl, Kai 2019. Natalie Mei ja soolisus. Seminaril "20. sajandi alguse Eesti kväärimine” 15.03.2019 Eesti Kirjandusmuuseumis peetud ettekanne (avaldamata).

\section{Kirjandus}

Annuk, Eve 2013. In Search of an Autobiographical Room of Her Own: First Estonian Feminist Lilli Suburg (1841-1923) as an Autobiographer. Aspasia. International Yearbook of Central, Eastern, and Southeastern European Women's and Gender history. Berghahn., lk 1-18 (doi: 10.3167/asp.2013.070102). 
Annuk, Eve 2016. Haigused ja igatsused. Lilli Suburgi käänuline tee. Keel ja Kirjandus 7, lk 539-552 (http://kjk.eki.ee/ee/issues/2016/7/811 - 31. jaanuar 2020).

Annuk, Eve 2019. Lilli Suburg's (1841-1923) feminist dream: Suburg as an editor of magazine Linda. Women editors in Europe, 1710-1920, 28-29 May 2019, Ghent University, Belgium.

Barad, Karen 2007. Meeting the Universe Halfway. Quantum physics and the entanglement of matter and meaning. Duke University Press.

Davidjants, Brigitta (toim) 2010. Kapiuksed valla. Arutlusi homo-, bi-ja transseksuaalsusest. Tallinn: Eesti Gei Noored.

Eesti rahva tulevik 1935 = Lüüs, Aadu \& Madissoon, Hans \& Peerandi, Adolf \& Vilms, Juhan (toim). Eesti rahva tulevik. II rahvusliku kasvatuse kongressi kõned ja läbirääkimised. Tartu: Tulevik.

Elberskirchen, Johanna 1925. Naise suguelu. Ploss, Hermann Heinrich. Naisterahvas: tema kehaehitus, suguelu ja tervishoid. Tartu: Rahvakirjandus, lk XX.

Ernits, Villem 1918-1919. Mõned hiljuti ilmunud Saksa-Eesti ja Eesti-Saksa keele õpperaamatud. Veski, Johannes Voldemar (toim). Eesti kirjandus: Eesti kirjanduse seltsi väljaanne. Kolmasteistkümnes aastakäik, lk 76-91.

Fausto-Sterling, Anne 2000. The five sexes, revisited. The Sciences 40, July-August, lk 18-23.

Freedman, Estelle 1982. Resources for Lesbian History. Cruikshant, Margaret (toim). Lesbian Studies. Present and Future. Old Westbury, N.Y.: Feminist Press, lk 110-113.

Forel[1], August[e] 1922. Suguelu vaimline tervishoid. Gruber, Max von. Suguelu tervishoid. Tartu: Noor-Eesti, lk XX.

Gould, Stephen Jay 1996. American Polygeny and Craniometry before Darwin. The Mismeasure of Man. New York: W.W.Norton \& Company, lk 62-104.

Heineman, Elizabeth 2002. Sexuality and Nazism: The Doubly Unspeakable? Journal of the History of Sexuality, Vol. 11, No. 1/2, Special Issue: Sexuality and German Fascism (Jan. - Apr., 2002), lk. 22-66 (doi: 10.1353/sex.2002.0006).

Hinrikus, Rutt 2016. Kahe vahel. Artikleid kirjandusest ja elulugudest. Tartu: Eesti Kirjandusmuuseumi Teaduskirjastus.

Hirschfeld, Magnus 1910. Die Transvestiten; ein Untersuchung über den erotischen Verkleidungstrieb: mit umfangreichem casuistischen und historischen Material. Lepzig: Medicinischer Verlag.

Ird, Ken 2013. Sodoomiajuhtumid varauusaegses Eestis Pärnu maakohtu materjalide põhjal. Magistritöö. Tartu Ülikool (https://dspace.ut.ee/handle/10062/33648 - 31. jaanuar 2020).

Kalkun, Andreas 2018. Ajalugu, mida polnud? Homoseksuaalse iha jäljed kolmes kohtuasjas. Mäetagused 71, lk 143-174 (doi: 10.7592/MT2018.71.kalkun).

Kalkun, Andreas 2020. Homoseksuaalsuse sõnastamise katsed. Eulenburgi skandaal ja Magnus Hirschfeld XX sajandi alguse Eesti ajakirjanduses. Keel ja Kirjandus 1-2, lk 112-132 (http://keeljakirjandus.ee/ee/issues/2020/1-2/1246 - 20. veebruar 2020). 
Kalling, Ken 2007. The Self-Perception of a Small Nation: The Reception of Eugenics in Interwar Estonia. Turda, Marius \& Weindling, Paul J. (toim). Blood and Homeland. Eugenics and Racial Nationalism in Central and Southeast Europe, 1900-1940. Budapest: CEU Press. lk 253-262.

Kalling, Ken 2013. The Application of Eugenics in Estonia 1918-1940. Felder, Bjorn M. \& Weindling, Paul J. (toim). Baltic Eugenics. Bio-Politics, Race and Nation in Interwar Estonia, Latvia and Lithuania 1918-1940. New York: Rodopi, lk 49-82 (doi: 10.1163/9789401209762_005).

Kalling, Ken \& Heapost, Leiu. Racial Identity and Physical Anthropology in Estonia 1800-1945. Felder, Bjorn M. \& Weindling, Paul J. (toim). Baltic Eugenics. Bio-Politics, Race and Nation in Interwar Estonia, Latvia and Lithuania 1918-1940. New York: Rodopi, lk 82-114 (doi: 10.1163/9789401209762_006).

Koobak, Redi 2013. Whirling Stories. Postsocialist Feminist Imaginaries and the Visual Arts. Doctoral thesis. Linköping University (doi: 10.13140/RG.2.1.1172.0402).

Krause, Wilhelm Ernst 1925. Quantitative Untersuchungen über experimentellen Hermaphroditismus. Väitekiri. Tartu Ülikool.

Kukke, Hugo 1935. Ajakirjanduse ülesandeid rahvusliku iseteadvuse kasvatuse ja eugeenika töös. Lüüs, Aadu \& Madissoon, Hans \& Peerandi, Adolf \& Vilms, Juhan (toim). Eesti rahva tulevik. II rahvusliku kasvatuse kongressi kõned ja läbirääkimised. Tartu: Tulevik, lk 100-102.

Lellep 1922 = Lellep, V. Uuemad vaated homoseksualiteedi üle. Eesti Arst (3) lk 142-144

Madisson, Hans 1927. Alaväärtuslikkude ja kurikalduvustega isikute suguvõimetuks tegemine. Audova, Aleksander \& Lüüs, Aadu \& Madisson, Hans \& Vilms, Juhan (toim). Pärivus ja valik: tõutervishoiu käsiraamat. Tartu: Loodus, lk 301-340.

Muñoz, José Esteban 1996. Ephemera as Evidence: Introductory Notes to Queer Acts. Women and Performance: A Journal of Feminist Theory 8, no. 2. lk 5-16 (doi: 10.1080/07407709608571228).

Mäelo, Helmi 1935. Arutelu P. Kogermanni ettekande Rahva mahutuse võimalusi tööstuses järel. Lüüs, Aadu \& Madissoon, Hans \& Peerandi, Adolf \& Vilms, Juhan (toim). Eesti rahva tulevik. II rahvusliku kasvatuse kongressi kõned ja läbirääkimised. Tartu: Tulevik.

Nõgel, Ivika 1991. How Homosexuality is Regarded among Students in Current Estonia. Parikas, Udo \& Veispak, Teet (toim). Sexual Minorities and Society: the changing attitudes towards homosexuality in the 20th century Europe. Papers presented to the international conference in Tallinn, May 28-30, 1990. Tallinn: Ajaloo Instituut, lk 115-121.

Samma, Jaanus 2011. Jutustamata lood. Audioteos nelja intervjuuga ning nende inglise keelde tõlgitud transkriptsioonid näituse "Sõnastamata lood" ajalehe insertidena.

Samma jt 2015 = Samma, Jaanus \& Viola, Eugenio \& Rünk, Martin \& Põldsam, Rebeka (koost) 2015. Not suitable for work. A chairman's tale. Berlin: Sternberg Press \& Tallinn: Center for Contemporary Arts.

Semper, Johannes 1926. Niidukressid. Ellinor. Tartu: Loodus, lk 55-98. 
Somerville, Siobhan 1994. Scientific Racism and the Emergence of the Homosexual Body. Journal of the History of Sexuality 5 (2, Oct., 1994), lk 243-266.

Stryker, Susan 2017. Transgender History. Thre roots of today's revolution. Revised edition. New York: Seal Press.

Taavetti, Riikka 2018a. Queer Politics of Memory: Undisciplined Sexualities as Glimpses and Fragments in Finnish and Estonian Pasts. Doctoral dissertaion. University of Helsinki (http://urn.fi/URN:ISBN:978-951-51-3330-4 - 5. veebruar 2020).

Taavetti, Riikka 2018b. On the limits of the diaspora narrative: The many lives of Heljo Liitoja. The 2018 Annual Conference of the Centre of Excellence in Estonian Studies "On the Move: Migration and Diasporas", Nov 29 - Dec 1. Abstracts (https://www.folklore.ee/ CEES/migrationdiaspora2018/wp-content/uploads/2018/11/abstracts.pdf - 5. veebruar 2020).

Tammeveski, Peeter 2005. Reproducing the gendered and racialized body of the nationstate: changing discourses of Estonian national identity in the homeland and diaspora. Doctoral dissertaion. Ann Arbor: Pennsylvania State University.

Treumund, Anna-Stina 2013. Lilli, Reed, Frieda, Sabine, Eha, Malle, Alfred, Rein and Mari. Tallinn: Lugemik.

Turner Carney, Maria 2018. \#Twinning: When Femme Lesbian Couples Start to Dress Alike. After Ellen (https://www.afterellen.com/lifestyle/advice-column/475487-twinninglesbian-couples-start-dress-alike\#obCMKLLsrfudyEV9.99 - 31. jaanuar 2020).

Veispak, Teet 1991. Homosexuality in Estonia in the 20th Century: Ideological and Juridical Aspects. Parikas, Udo \& Veispak, Teet (toim). Sexual Minorities and Society: the changing attitudes towards homosexuality in the 20th century Europe. Papers presented to the international conference in Tallinn, May 28-30, 1990. Tallinn: Ajaloo Instituut, lk 105-114.

ÕS 1925 = Veski, Johannes Voldemar 1925. Eesti õigekeelsuse-sõnaraamat. I köide, A-M. Tartu: Eesti Kirjanduse Selts.

\title{
Summary
}

\section{Looking for queer stories from interwar Estonian media: The position of eugenics in discussions about homosexuality and transgender issues}

\author{
Rebeka Põldsam \\ Doctoral student of ethnology \\ University of Tartu, Estonia
}

Keywords: history of sexuality, interwar period in Estonia, Karen Barad's agential realism, LGBTQI+ media studies 
In order to build a better understanding of what sexuality meant in interwar Estonia and how it was expressed, this article focuses on representations of sexual and gender minorities in the Estonian printed media of the 1920s-1930s. On the one hand, seldom if ever, I found immediate voices of the marginalised people in focus, while on the other hand, many of the terms to describe sexual diversity were in the process of being articulated or had not been defined by that time. This lack of definitions, however, creates an epistemological gap between the present day and the interwar period, which I am aiming to reduce with this article. Hence, in order to demonstrate the development of sexuality-related terminology through time, I start with a brief survey of Estonian LGBTQI+ historiography. Next, I map the journalistic and scientific articles on sex and gender minorities in interwar Estonia. Finally, I present a case study of a so-called male-woman A. Oinatski, who was the most frequently and diversely portrayed queer person in Estonia during the interwar era. To systematize and differentiate the found fragmented sources, I apply feminist theorist Karen Barad's model of agential realism, which helps to notice nuanced relationships between various examples of discourse around sexual minorities during the interwar era. Finally, I look at how the eugenics movement influenced the depictions and concepts of sex and gender in the public discussions held in interwar Estonia.

Rebeka Põldsam on Tartu Ülikooli etnoloogia doktorant, kes uurib Eesti seksuaal- ja soovähemuste elu- ja ajalugusid 20. sajandi algusest tänapäevani. Ta on lõpetanud kunstiteaduse bakalaureuse Eesti Kunstiakadeemias ning kaasaegse kunsti teooria magistri Londoni Ülikooli Goldsmithsi kolledžis. 2019. aasta kevadel täiendas ta end külalisuurijana Santa Cruzi Kalifornia Ülikoolis. Aastail 2012-2017 töötas Põldsam projektijuhi-kuraatorina Kaasaegse Kunsti Eesti Keskuses. Ta on vabakutseline feministlik kunstikriitik, kuraator ning õpetanud kunstiajalugu ja -teooriat külalislektorina erinevates Eesti ülikoolides.

Rebeka Põldsam is a doctoral student of ethnology at the University of Tartu, where she studies oral histories of sexual and gender minorities of Estonia from the beginning of the 20th century until present. She has a BA in Art History from the Estonian Academy of Arts and an MA in Contemporary Art Theory from Goldsmiths College, University of London. In spring 2019 she was a visiting scholar at the University of California, Santa Cruz. In 2012-2017 Põldsam worked as a curator-project manager at the Center for Contemporary Arts, Estonia. She is a freelance feminist art critic and curator, and she has taught art history and art theory at various Estonian universities.

rebekap@gmail.com 